\title{
Cave monitoring in the Béke and Baradla caves (Northeastern Hungary): implications for the conditions for the formation cave carbonates
}

György Czuppon 1,3* Attila Demény ${ }^{1}$, Szabolcs Leél-Őssy ${ }^{2}$, Mihály Óvari ${ }^{4}$ Mihály Molnár ${ }^{3}$ József Stieber ${ }^{5}$, Klaudia Kiss ${ }^{6}$, Krisztina Kármán ${ }^{1}$, Gergely Surányi ${ }^{7}$, and László Haszpra ${ }^{8,9}$

${ }^{1}$ Institute for Geological and Geochemical Research, RCAES, Hungarian Academy of Sciences, Budaörsi út 45, Budapest, H-1112, Hungary

${ }^{2}$ Department of Physical and Applied Geology, Eötvös Loránd University, Pázmány Péter sétány 1/C, Budapest, H-1117, Hungary

${ }^{3}$ Institute for Nuclear Research, Hungarian Academy of Sciences, Bem tér 18/C, Debrecen, H-4026, Hungary

${ }^{4}$ Centre for Ecological Research of the Hungarian Academy of Sciences, Danube Research Institute, Karolina út 29-31, Budapest, H-1113, Hungary

${ }^{5}$ Stieber Environmental Ltd., Nyerges u. 6, Budapest, H-1181, Hungary

${ }^{6}$ Department of Physical Geography, Eötvös Loránd University, Pázmány Péter sétány 1/C, Budapest, H-1117, Hungary

${ }^{7}$ MTA-ELTE Geological, Geophysical and Space Sciences Research Group, Pázmány Péter s. 1/C, Budapest, H-1117, Hungary

${ }^{8}$ Geodetic and Geophysical Institute, Research Centre for Astronomy and Earth Sciences, Hungarian Academy of Sciences, Csatkai E. u. 6-8,

Sopron, H-9400, Hungary

${ }^{9}$ Hungarian Meteorological Service, Gilice tér 39, Budapest, H-1181, Hungary

\begin{abstract}
In order to use speleothems in the reconstruction of past climate and environmental changes it is necessary to understand the environmental and hydrological processes that determine the physico-chemical conditions of carbonate precipitation and hence speleothem formation. Therefore, in this study an extended monitoring program was conducted in the Béke and Baradla caves located in the Aggtelek region (Northeastern Hungary). The studied caves are rich in speleothem and flowstone occurrences with great potential for paleoclimatology studies. The monitoring activity included measurements of atmospheric and cave temperatures, $\mathrm{CO}_{2}$ concentration in cave air, as well as chemical and isotopic compositions of water samples (drip water, precipitation) and in situ carbonate precipitates. The hydrogen and oxygen isotope compositions of drip waters showed no seasonal variation at any of the collection sites, indicating a well-mixed karstic aquifer. This implies that the isotopic compositions of local speleothems were able to record multiannual isotopic changes inherited from stable isotopes in the drip water. $\mathrm{CO}_{2}$ concentration showed seasonality (high values in summer and low values in winter) in both caves, likely affecting carbonate precipitation or corrosion and consequently stalagmite growth. Systematic variations among $\mathrm{Mg} / \mathrm{Ca}$ and $\mathrm{Sr} / \mathrm{Ca}, \mathrm{Na} / \mathrm{Ca}$, and $\mathrm{Si} / \mathrm{Ca}$ element ratios were detected in the drip water suggesting Prior Calcite Precipitation (PCP). As PCP is characteristic of periods of reduced infiltration during drier weather conditions, the variations in drip water chemistry and drip rates indicate that the hydrological conditions also varied significantly during the studied period. This hydrological variability appears to affect not only trace element composition but also the isotopic composition of modern carbonate precipitates. In summary, these findings imply that the speleothems from the studied caves were able to record the hydrological changes resulting from alternating wet and dry periods, and therefore the geochemical data can be used to reconstruct past climate and environmental changes.
\end{abstract}

Keywords: Béke, Baradla, cave monitoring, PCP, stable isotope, fresh carbonate precipitates

Received 31 December 2016; Revised 28 October 2017; Accepted 30 October 2017

Citation: C Czuppon G., Demény A., Leél-Őssy S., Óvari M., Molnár M., Stieber J., Kiss K., Kármán K., Surányi G. and Haszpra L., 2018. Cave monitoring in the Béke and Baradla caves (Northeastern Hungary): implications for the conditions for the formation cave carbonates. International Journal of Speleology, 47 (1), 13-28. Tampa, FL (USA) ISSN 0392-6672 https://doi.org/10.5038/1827-806X.47.1.2110

\section{INTRODUCTION}

A recent compilation of present-day knowledge on the formation of speleothems by Fairchild and Baker (2012) presents numerous examples of why speleothems are one of the most valuable terrestrial paleoclimate archives. The main advantages of speleothems in paleoclimate research compared to other continental sedimentary deposits are their formation in cave environments where late-stage alterations are not significant, the possibility of radiometric age determinations by the U-Th series 
and radiocarbon dating methods, and the various geochemical data (especially stable isotope and trace element compositions) that serve as proxies of past environmental conditions. The Carpathian Basin region contains several caves where stalagmites have already been collected and studied to determine temperature and precipitation variations over the last 10,000 years (Siklósy et al., 2009a,b; 2011; Demény et al., 2013; 2017). The Baradla and Béke caves of the Aggtelek karst system, located in the northeastern part of the Carpathian Basin, may provide an especially good base for speleothem-related paleoclimate research as they are rich in speleothem formations. Speleothem deposits range from small, fragmentary stalagmites and stalactites in allochtonous positions due to tectonic movements or earlier cave exploration work, to large and precious intact formations that are highly protected and cannot be sampled. Other types of speleothem deposition include tufa dams and flowstones that form in permanent or temporary water flows. The advantage of these latter deposits may be their easier access for sampling and the possibility of re-sampling by drilling if needed to demonstrate the replication of geochemical records (Meyer et al., 2008; Boch \& Spötl, 2011; Spötl \& Mattey, 2012; Wainer et al., 2013; Regattieri et al., 2014). Paleoclimate studies on any of these speleothem deposits require the knowledge of whether i) they formed in isotopic equilibrium with ambient water or have been affected by kinetic fractionation processes, ii) their geochemical compositions reflect environmental parameters with relationships that can be applied in paleoclimate research, and iii) they can be dated by radiometric dating methods with appropriate precision. This study presents the results of a 3-year program monitoring the physico-chemical parameters of cave sites and drip waters and explores the conditions of different carbonate precipitates in order to provide a basis for further paleoclimate studies on speleothems.

\section{THE GEOLOGICAL AND ENVIRONMENTAL SETTING OF THE CAVES}

The Béke $\left(48^{\circ} 29^{\prime} \mathrm{N}, 20^{\circ} 31^{\prime} \mathrm{E}\right)$ and Baradla $\left(48^{\circ} 28^{\prime} \mathrm{N}\right.$, $20^{\circ} 30^{\prime}$ E) caves are mainly situated in the GömörTorna karst, northeastern Hungary and partly in Slovakia (Fig. 1). Both studied caves are part of the Aggtelek National Park and constitute a UNESCO World Heritage site. The caves are located 2-3 km apart and both are developed in Guttenstein Limestone (with dolomitic layers), Steinalm Limestone and Wetterstein Limestone (Triassic lagoon facies carbonates) (e.g., Hips, 2003). The caves are located under open karst, thus karstic forms dominate on the surface. However, the karst above the Béke Cave seems to be more rugged, which is probably related to the dominant presence of Steinalm Limestone on the surface. Both caves have a perennial cave stream but the water levels display fluctuation over a year. The Béke and Baradla caves developed in a similar way, but the catchment area is substantially larger in the case of the Baradla Cave, therefore, the amount of sediment carried by the water is larger, resulting in greater chambers and passages. The majority of the catchment area is covered by forest and meadow. Thus, the typical soil types in the area are Rendzina, and Cambisol-Terra.

The Béke Cave is about $7 \mathrm{~km}$ long (in total) and the main entrance is situated at about $338 \mathrm{~m}$ a.s.1. The main passage is about $4,300 \mathrm{~m}$ long and has two side branches connected to it (Felfedező ág and Kavicsos ág; Fig. 1). There are three entrances: two natural and one artificial. The natural entrances are located in the Felfedezö-ág (side branch) and in the main passage nearby the settlement of Jósvafo,, while the artificial entrance, opened in 1953, is located close to the south end of the main passage. The thickness of the overburden is around $30-60 \mathrm{~m}$. A total of four sites were selected in this cave along the main passage to perform regular monthly monitoring. The sites are located at different distances from the main entrance: 1) Nagy-tufa (B-NT, 120 m), 2) Felfedező ág (B-FA, $250 \mathrm{~m})$, 3) point B560 (B-560 m), and 4) Buzogány Hall (B-BZ, 1560 m) (Fig. 1).

The Baradla cave system is substantially larger than Béke Cave, with a total length of $>25 \mathrm{~km}$. The Slovakian part is called Domica Cave. One site (Nehéz-út: BARNU) was selected for monitoring in the Baradla Cave, approximately $1,100 \mathrm{~m}$ from the main entrance along the main passage (Fig. 1). There are also several side branches connected to main passage. The thickness of the overburden above the studied site is around 90-100 m.

The studied area belongs to the temperate climate zone. The long term average annual precipitation is $665 \mathrm{~mm}$, and the long term mean annual temperature is $8.3^{\circ} \mathrm{C}$ (for the period 1961-2010, Carpatclim, Szalai et al., 2013). The majority of the annual precipitation fell in the period from May to July, but potential evapotranspiration is also the largest in these months (on the basis of the Carpatclim, Szalai et al., 2013), determining the amount of effective infiltration.

The monthly meteorological data was taken from the Jósvafö Meteorological Station (Meteo Station in Fig. 1; Hungarian Meteorological Service). Total annual precipitation was $725 \mathrm{~mm}, 684 \mathrm{~mm}$, and $527 \mathrm{~mm}$ for 2013, 2014, and 2015, respectively (Supplemental Table 1). Based on the data recorded at the meteorological station at Jósvafó the mean annual temperature was $9.6^{\circ} \mathrm{C}, 10.6^{\circ} \mathrm{C}$, and $10.4^{\circ} \mathrm{C}$ for 2013, 2014, and 2015, respectively. The long term mean annual temperature is $8.3^{\circ} \mathrm{C}$ (Szalai et al., 2013) showing a lower temperature than over the studied period (Supplemental Table 1). Indeed, the average monthly temperatures in 2013 and 2015 were systematically higher than the long term average value in almost every month.

\section{MATERIALS AND METHODS}

\section{Monitoring}

In the Béke Cave systematic monitoring was conducted between January, 2013 and July, 2015, followed by occasional collection and measurement activities until April, 2016. Four sites (Nagy-tufa: B-NT, Felfedező-ág: B-FA, the B560 site: B-560, 

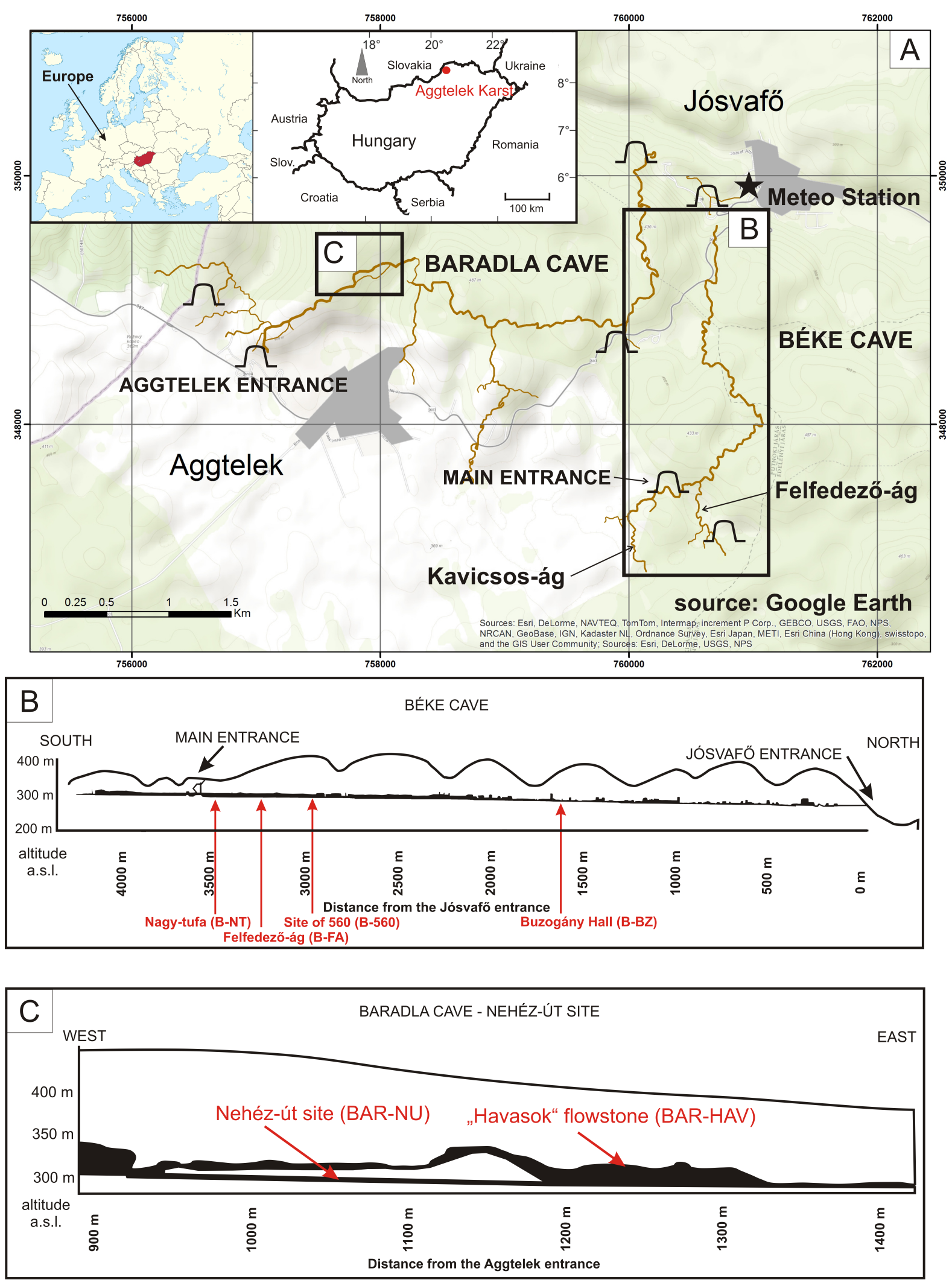

Fig. 1. Location of the caves (A) near to Aggtelek and Jósvafö towns (grey areas) and the studied sites within the Béke Cave (B) and Baradla Cave (C) (modified after Demény et al., 2017).

Buzogány-Hall: B-BZ) were visited every month. The monitoring activity within the cave system included measurements of climatological parameters (temperature, relative humidity, pressure, and cave air $\mathrm{pCO}_{2}$ ), drip rate and collection of water samples for different parameters. Air pressure was measured barometrically using a GTD 1100 device $( \pm 1.5 \mathrm{hPa})$. Air temperature and relative humidity were measured manually using a Testo 610 device (temp.: $\pm 0.5^{\circ} \mathrm{C}$ in the range between $-10^{\circ} \mathrm{C}$ and $+50^{\circ} \mathrm{C}$, humid.: $\pm 25 \%$ at $0-100 \%$ ). Cave air $\mathrm{pCO}_{2}$ was measured using a portable $\mathrm{CO}_{2}$ meter (Testo $535 ; \pm 3 \%$ of the value).

Different "types" of water were collected within the caves: 1) drip water collected for approximately a month (time between two visits; $32 \pm 9$ days); 2) fresh drip water collected during visits; 3 ) stream water; and 4) water from which flowstones form at the Nagy-tufa site. The "monthly" drip water was collected using a funnel connected to a plastic tube and a bottle. Thus, it was possible to avoid significant evaporation. The 
Nagy-tufa site flowstone was dry for most of the time allowing us to take water samples only on seven occasions. Both the electrical conductivity and $\mathrm{pH}$ values of the water samples were always measured at the site. The electrical conductivity (EC) and $\mathrm{pH}$ were measured using a Combo device (HI98129; pH: \pm 0.05 in the range between 0 and 14; electrical conductivity: $\pm 2 \%$ in the range between 0 and $3999 \mu \mathrm{S} / \mathrm{cm}$ ). The results of electrical conductivity and $\mathrm{pH}$ are given following temperature calibration.

Additionally, calcite farming was conducted by putting light bulbs (with a form analogous to a stalagmite top) under two active drip sites in the Buzogány Hall, Béke Cave. The two sites (site I and site II) were located on the same side in the chamber (about $4 \mathrm{~m}$ from each other; see Supplementary Material: Supplemental Fig. 1). A third site (site III) was chosen for calcite farming at the end of September 2015 when both site I and site II became inactive. The positions of the bulbs are indicated in the map of Buzogány Hall (see Supplementary: Fig. 1). The bulbs were left in the cave for several months to allow a sufficient amount of carbonate deposition. The light bulbs were treated using $\mathrm{SiC}$ grinding powder in order to produce a rough surface and hence seed sites for carbonate precipitation. Following collection the bulbs were dried and the carbonate scraped off using a sharp knife from different parts of the bulb. When the water drips hit the bulbs at well-defined points, the carbonate was sampled at the top and the flanks as well. In some cases the bulbs were moved by the dripping water and so the relative position of carbonate deposition was not clearly distinguished.

One site (Nehéz-út) was visited in the Baradla Cave during the monitoring campaign. Between 2013 and 2015 fresh drip water samples were collected 19 times. The $\mathrm{CO}_{2}$ concentration and the temperature measurements were started much earlier (1994) at this site resulting in much longer data series. These measurements were carried out four times a year to reveal seasonal differences. In addition, actively forming stalagmites and flowstones were also sampled at the Nehéz-út site of the Baradla Cave. The internal textural and geochemical characteristics of the stalagmites are described by Demény et al. (2017), in this study we focus on the youngest part of the NU-2 stalagmite, which was selected as the most appropriate for detailed studies by Demény et al. (2017). The carbonate samples were drilled from the surface and from the youngest $3 \mathrm{~mm}$ part (representing 10 years from 1999 to 2010) of a polished cross-section using a $0.6 \mathrm{~mm}$ drill bit and a hand-held drilling machine. Additionally surficial samples of an actively forming flowstone ("Havasok") close to the water discharge point were also collected near to the Nehéz-út sampling site (Fig. 1).

Meteorological parameters were measured above Béke Cave (next to the main entrance; Fig. 1), such as air temperature, relative humidity, pressure and $\mathrm{pCO}_{2}$. Precipitation water was collected every month at the same place using a funnel connected with tube to a five liter bottle (to avoid significant evaporation). The daily and monthly meteorological data were taken from the Jósvafö Meteorological Station (Meteo Station in Fig. 1; Hungarian Meteorological Service). The Carpatclim database (Szalai et al., 2013) was used to characterize long term climatological parameters (temperature, precipitation) at the studied site.

The potential evapotranspiration was calculated by using the daily meteorological data and applying the equation of Haude (1955) and following the procedure described in Riechelmann et al. $(2011,2017)$ and Mischel et al. (2015):

$\mathrm{ET}_{\mathrm{p}}[\mathrm{mm} /$ day $]=\chi[\mathrm{mm} /$ day $] \times \mathrm{P}[\mathrm{hPa}] \times[1-(\mathrm{F}[\%] / 100)]$

where $\mathrm{ET}_{\mathrm{p}}$ is potential evapotranspiration ( $\mathrm{mm} /$ day), $\mathrm{x}$ represents a coefficient depending on vegetation, $\mathrm{p}$ is saturation vapor pressure $(\mathrm{hPa})$ and $\mathrm{F}$ is relative humidity. The saturation pressure was calculated using the Magnus-formula:

$$
\mathrm{P}[\mathrm{hPa}]=6,107[\mathrm{hPa}] \times 10^{\left(\left(7.5 \times \mathrm{T}\left[{ }^{\circ} \mathrm{C}\right]\right) /\left(237+\mathrm{T}\left[{ }^{\circ} \mathrm{C}\right)\right)\right.}
$$

$\mathrm{T}$ is air temperature. The amount of infiltrating water during a month $\left(\operatorname{Inf}_{\mathrm{MONTH}}\right)$ was calculated by the following equation:

$$
\operatorname{Inf}_{\text {MONTH }}[\mathrm{mm}]=\Sigma \operatorname{Prec}_{\mathrm{i}}[\mathrm{mm}]-\Sigma \mathrm{ET}_{\mathrm{p}, \mathrm{i}}[\mathrm{mm}]
$$

where $\operatorname{Prec}_{\mathrm{i}}$ and $\mathrm{ET}_{\mathrm{p}, \mathrm{i}}$ are daily precipitation and potential evapotranspiration, respectively. If monthly $\mathrm{ET}_{\mathrm{p}}$ is higher than the amount of monthly precipitation, resulting in a negative value for $\operatorname{Inf}_{\text {MONTH }}$ [Eq. (4)], the corresponding value was set to zero.

\section{Analytical methods}

Stable carbon and oxygen isotope compositions of approximately 150-200 $\mathrm{\mu g}$ carbonate samples were determined applying the carbonate-orthophosphoric acid reaction at $72{ }^{\circ} \mathrm{C}$ (Spötl \& Vennemann, 2003) and using an automated GASBENCH II sample preparation device attached to a Thermo Finnigan Delta Plus XP mass spectrometer at the Institute for Geological and Geochemical Research (IGGR) in Budapest, Hungary. Isotopic compositions of carbonate samples are expressed as $\delta^{13} \mathrm{C}$ and $\delta^{18} \mathrm{O}$ in \%o relative to $\mathrm{V}$-PDB (Vienna Pee Dee Belemnite), with a precision better than $\pm 0.1 \%$, based on replicate analyses of samples and international standards (NBS-18, NBS-19 and LSVEC) supplied by the International Atomic Energy Agency. Stable isotope analyses of the water samples were carried out also at the IGGR using a LiquidWater Isotope Analyser-24d by Los Gatos Research. The instrument uses off-axis integrated cavity ring down spectroscopy to measure the absolute abundances of ${ }^{2} \mathrm{H}^{1} \mathrm{H}^{16} \mathrm{O},{ }^{1} \mathrm{H}^{1} \mathrm{H}^{18} \mathrm{O}$ and ${ }^{1} \mathrm{H}^{1} \mathrm{H}^{16} \mathrm{O}$ via laser absorption. We used homemade laboratory standards, which were calibrated to international standards $\left(\delta \mathrm{D}=-9.0 \%\right.$; $-74.9 \%$ \% $-147.7 \%$; $\delta^{18} \mathrm{O}=-0.53 \%$; $-10.41 \%$; $-19.95 \%$ o for BWS1, BWS2, BWS3, respectively). The precisions are better than $1.0 \%$ o and $0.15 \%$ or hydrogen and oxygen isotope ratios, respectively. The isotopic compositions of the water samples are expressed as $\delta \mathrm{D}$ and $\delta^{18} \mathrm{O}$ in \%o relative to V-SMOW (Vienna Standard Mean Ocean Water; Coplen et al., 1996).

Trace element concentration measurements were conducted at the Institute of Chemistry, Eötvös 
Loránd University, Budapest, Hungary. About $10 \mathrm{mg}$ of powdered sample was weighed into high purity $15 \mathrm{~mL}$ polypropylene centrifuge vials using an ultramicro balance, then dissolved in $12 \mathrm{~mL}, 0.5 \mathrm{~mol} / \mathrm{dm}^{3}$ nitric acid (Suprapure grade, E. Merck, Darmstadt, Germany). For the quantification $120 \mu \mathrm{L}, 1 \mathrm{mg} / \mathrm{dm}^{3}$ of internal standard solution was added. The analysis was carried out using an Element 2 inductively coupled plasma sector field mass spectrometer (Thermo-Finnigan, Bremen, Germany) (see Demény et al., 2017 for more details).

Sample preparation for accelerator mass spectrometry (AMS) analyses were conducted following standard procedures (Molnár et al., 2013a), the ${ }^{14} \mathrm{C} /{ }^{12} \mathrm{C}$ and ${ }^{13} \mathrm{C} /{ }^{12} \mathrm{C}$ ratios were measured by the EnvironMICADAS ${ }^{14} \mathrm{C}$ facility at the Hertelendi Laboratory of Environmental Studies in Debrecen, Hungary (Molnár et al., 2013b). Activities are expressed in pMC (percent modern carbon). Overall measurement uncertainties for the modern samples are less than $0.3 \%$ including normalization, background subtraction, and counting statistics.

\section{RESULTS}

\section{Climatological parameters}

The Béke Cave exhibited a temperature range between 9.3 and $11.4^{\circ} \mathrm{C}$ with no seasonality, indicating a stable cave climate (Supplemental Table 2). There was a small but systematic temperature change with distance from the main entrance (Supplemental Table 2): the annual average temperatures were $9.8^{\circ} \mathrm{C}$, $10.1^{\circ} \mathrm{C}, 10.2^{\circ} \mathrm{C}$, and $10.4^{\circ} \mathrm{C}$ at B-NT, at B-FA, at the $\mathrm{B}-560$ site and at B-BZ, respectively, for the period 2013-2014. These values agreed well with the range of mean annual surface temperature $\left(9.6-10.6^{\circ} \mathrm{C}\right)$ recorded at the Jósvafó meteorological station, but were slightly higher than the long term average $\left(8.3^{\circ} \mathrm{C}\right.$ for the period 1961-2010, Carpatclim database, Szalai et al., 2013; and $8.8^{\circ} \mathrm{C}$ for the period 1961 2013, Jósvafö Meteorological station (Hungarian Meteorological Service). The relative humidity was consistently above $96 \%$ at each site during the monitoring campaign (Supplemental Table 2). The $\mathrm{CO}_{2}$ concentrations of the cave air showed strong

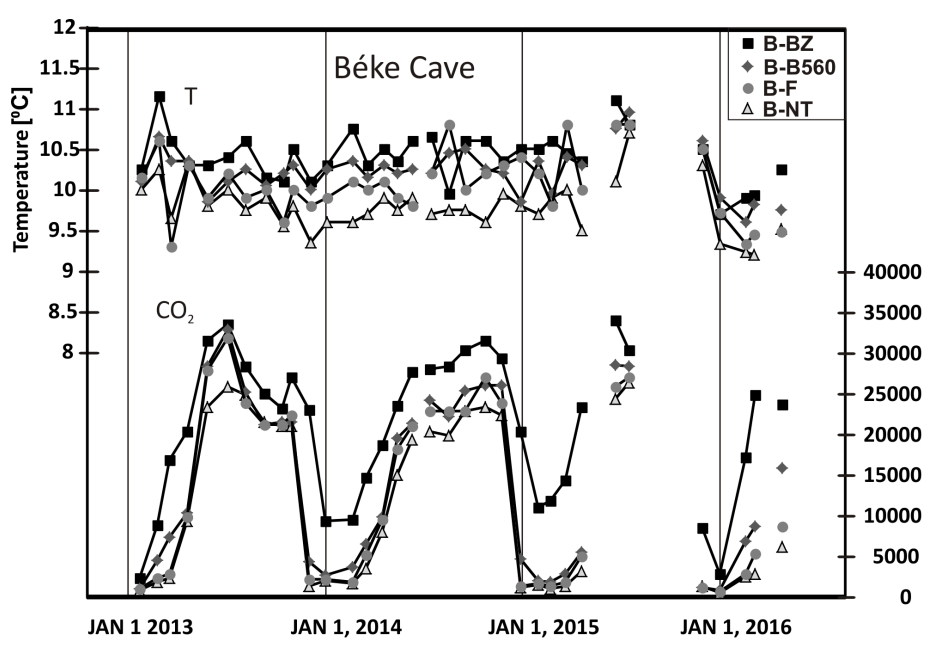

seasonality in the studied period. The summer months were characterized by high $\mathrm{CO}_{2}$ concentration $(25,000$ - 35,000 ppm), while the winter months exhibited lower $\mathrm{CO}_{2}$ concentrations $(1,000-3,000 \mathrm{ppm})$. The autumn and spring showed some middle values between those observed in summer and winter. Additionally, the $\mathrm{CO}_{2}$ concentrations showed a systematic increase with distance from the main entrance: the average $\mathrm{CO}_{2}$ concentrations (in the period of 2013 and 2014) were $13,800 \mathrm{ppm}, 15,200 \mathrm{ppm}, 16,300 \mathrm{ppm}$, and 22,400 ppm at B-NT, B-FA, B-560 and B-BZ sites, respectively (Fig. 2). The relatively high $\mathrm{CO}_{2}$ concentrations and the observed spatial distribution can be explained by blocked airflow towards the second entrance at Jósfafö (Fig. 1), resulting in a dead-end cave with limited ventilation (Stieber \& Leél-Őssy, 2015).

Although the monitoring activity was started in order to explore the Béke Cave's behavior, the Nehézút site in Baradla Cave, where several carbonate formations were collected (Demény et al., 2017), was also monitored. $\mathrm{CO}_{2}$ concentrations and temperature data were gathered and presented in this paper for the period 1994-2013 (Supplemental Table 3). The $\mathrm{CO}_{2}$ concentrations also varied seasonally in the Baradla Cave, with higher values in summer $(4,200 \mathrm{ppm})$ and lower values in winter $(1,600 \mathrm{ppm})$, generally much lower than those in Béke Cave (Fig. 2). Temperature varied between 9.8 and $10.5^{\circ} \mathrm{C}$. Within this narrow range, a clear seasonality can be observed (Fig. 2), as opposed to the Béke Cave's sites. The long term average is $10.2^{\circ} \mathrm{C}$, which is similar to that measured in Béke Cave.

\section{Chemistry of cave waters}

The electrical conductivity of drip waters showed seasonal variation following similar pattern to air temperature and amount of precipitation (Fig. 3). The average values of electrical conductivity of fresh drip water at the B-BZ the B-650 and the B-BZ sites were 560,680 , and $630 \mathrm{mS} / \mathrm{cm}$, respectively, for the studied period (2013-2014) (Supplemental Table 4). The stream water flowing at the study sites had similar values $(530,600$, and $660 \mathrm{mS} / \mathrm{cm})$. The electrical conductivity of monthly drip waters show seasonality with the lowest values in winter (Fig. 3).

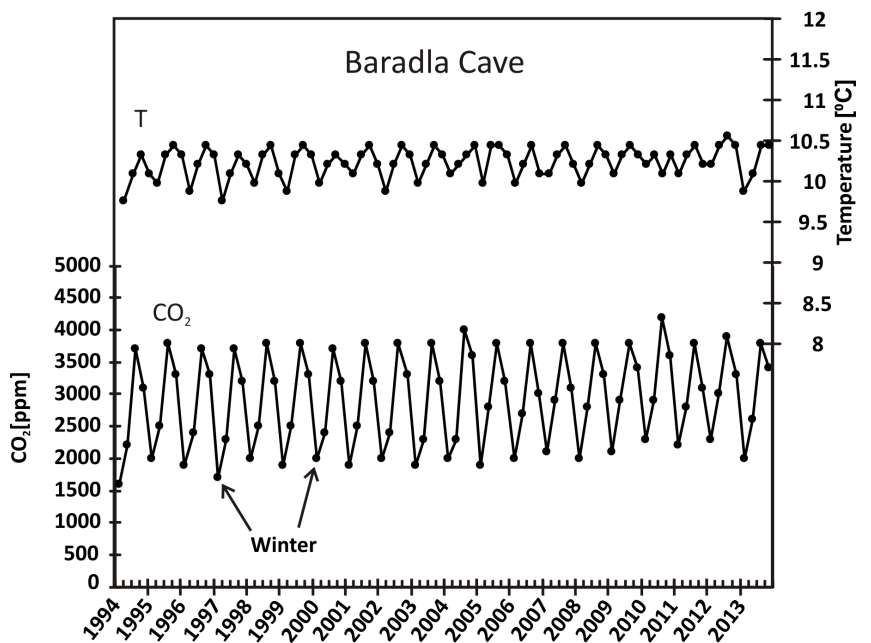

Fig. 2. Cave climate: variation of $\mathrm{CO}_{2}$ concentrations and temperature in the studied sites within Béke (B-NT = Nagy-tufa; B-FA = Felfedezö ág; B-560 = site of 560, B-BZ = Buzogány Hall) and Baradla (Nehéz-út: BAR-NU) caves. 


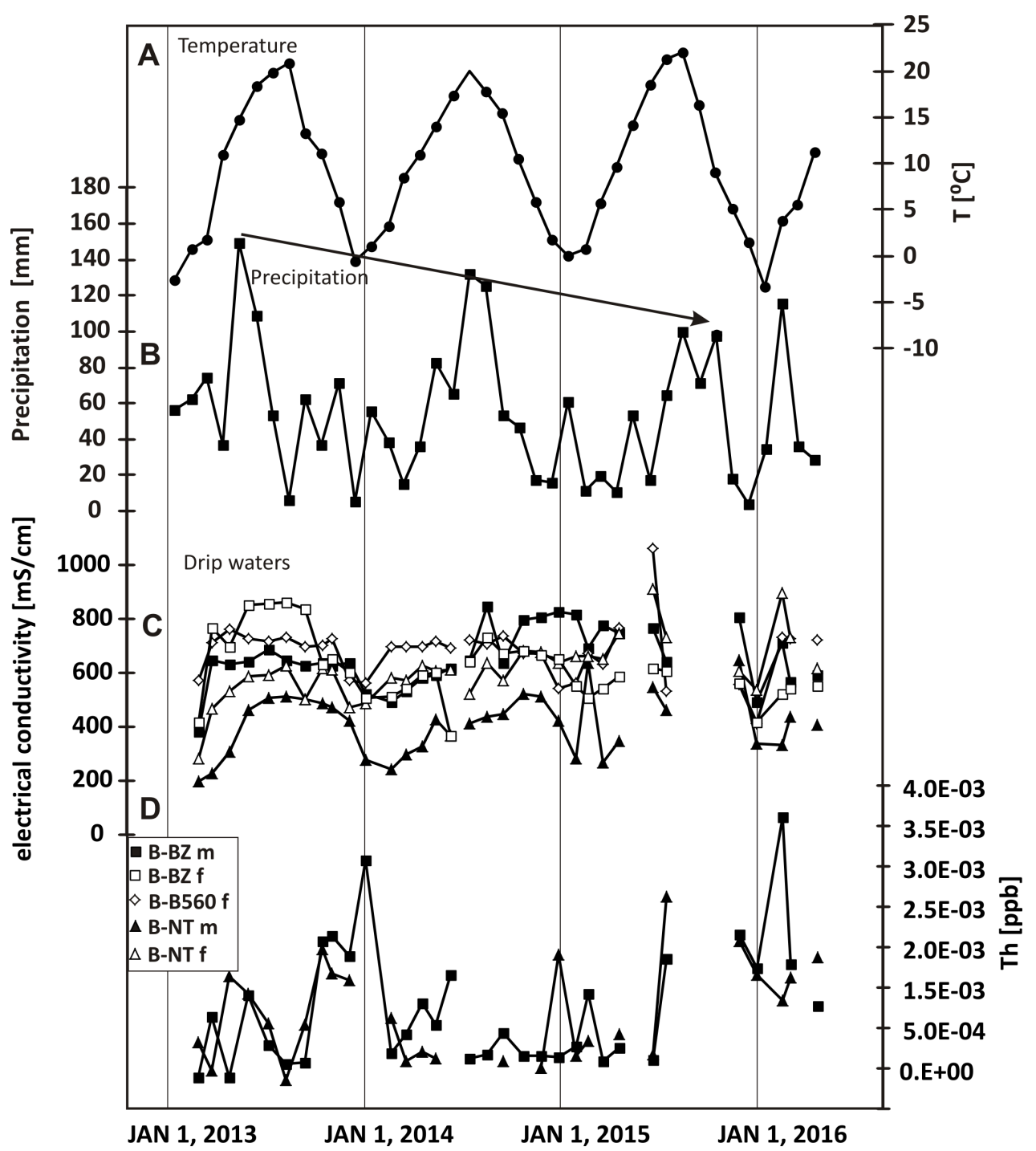

Fig. 3. Variation of outside temperature (A) and precipitation (B) and variation of electrical conductivity (C) and Th concentrations (D) measured in drip water at the sites in Béke Cave (B-NT $m=$ monthly drip water at Nagy-tufa; B-NT $f=$ fresh drip water at Nagy-tufa; B-560 $f=$ fresh drip water at the site of 560, $\mathrm{B}-\mathrm{BZ} \mathrm{m}=$ monthly drip water at Buzogány Hall; $\mathrm{B}-\mathrm{BZ} \mathrm{f}=$ fresh drip water at Buzogány Hall).

Th concentrations were highest during winter months (Fig. 3D), which might indicate more detrital material input as Th is an insoluble element in aqueous solution. Similarly to the electrical conductivity values, the $\mathrm{pH}$ values of the cave waters displayed seasonal changes: cold/warm months were characterized by low/high values (Fig. 4A). In addition to seasonal variation, a general increasing trend appears from January 2014 until the end of 2015.

Calcium (as the dominant cation in the drip water) showed seasonal variations (Supplemental Table 4) exhibiting the highest concentrations in summer months (Fig. 4B). Additionally, Ca concentrations displayed a continuous decrease over the studied period.

\section{Stable isotope composition of cave waters and precipitation}

Stable isotope compositions were determined for monthly drip water, fresh drip water and stream water in Béke Cave and the fresh drip water in Baradla Cave as well as for the monthly collected precipitation samples (Supplemental Tables 4-6). The stable isotope values of the precipitation collected above the caves fell between $-110.0 \%$ and $-19.5 \%$ for $\delta \mathrm{D}$ and $-15.5 \%$ and $-3.0 \%$ o for $\delta^{18} \mathrm{O}$. The isotope ratios of both elements ( $\mathrm{H}$ and $\mathrm{O}$ ) showed seasonal trends with high values in summer and low values in winter (Figs. 5 and 6). The Local Meteoric Water Line (LMWL) derived from the precipitation $\delta^{18} \mathrm{O}$ and $\delta \mathrm{D}$ values is $\delta \mathrm{D}=7.6 \times \delta^{18} \mathrm{O}+6.0$ (Fig. 7). This plots near to the Global Meteoric Water Line defined by Rozanski et al. (1993). The annual mean $\delta D$ and $\delta^{18} \mathrm{O}$ values of rain water, weighted by the amount of precipitation are $-62.3 \%$ and $-9.1 \%$, respectively. The amount weighted $\delta \mathrm{D}$ and $\delta^{18} \mathrm{O}$ values during summer and winter are around $-48.3 \%$ and $-7.2 \%$ ond $-71.3 \%$ o and $-10.19 \%$, respectively.

The stable isotope compositions of cave waters including drip, stream and spring waters showed low variability with very similar values at all of the studied sites in the Béke and Baradla caves (Supplemental Table 4, 5, and Figs. 5, 6). Additionally, no seasonal variation was observed during the studied period. The average $\delta \mathrm{D}$ and $\delta^{18} \mathrm{O}$ values of drip water in Béke Cave were $-64.6 \pm 1.5 \%$ ond $-9.4 \pm 0.2 \%$, respectively. The stable isotope compositions of drip water in Baradla Cave were characterized by very similar values $\left(\delta \mathrm{D}=-64.7 \pm 1.9 \%\right.$ ond $\delta^{18} \mathrm{O}=-9.4 \pm 0.3 \%$ o $)$ to those found in Béke Cave. These values are lower (more negative) relative to the isotopic composition of 
amount weighted annual precipitation $(\delta \mathrm{D}=-62.3 \%$ and $\delta^{18} \mathrm{O}=-9.1 \%$ ) .

\section{Drip rates}

The drip rates were determined during the cave visits (Supplemental Table 7). The drip rates of all drip sites (B-NT B-560, B-BZ- I and II sites) showed a seasonal cycle with minimum values during winter and a decreasing trend in general from October 2014 until January 2016. The studied sites were characterized by different drip rates; especially the drip at B-BZ sites showed a systematic variation during the whole monitoring campaign: site I had higher drip rates relative to site II.

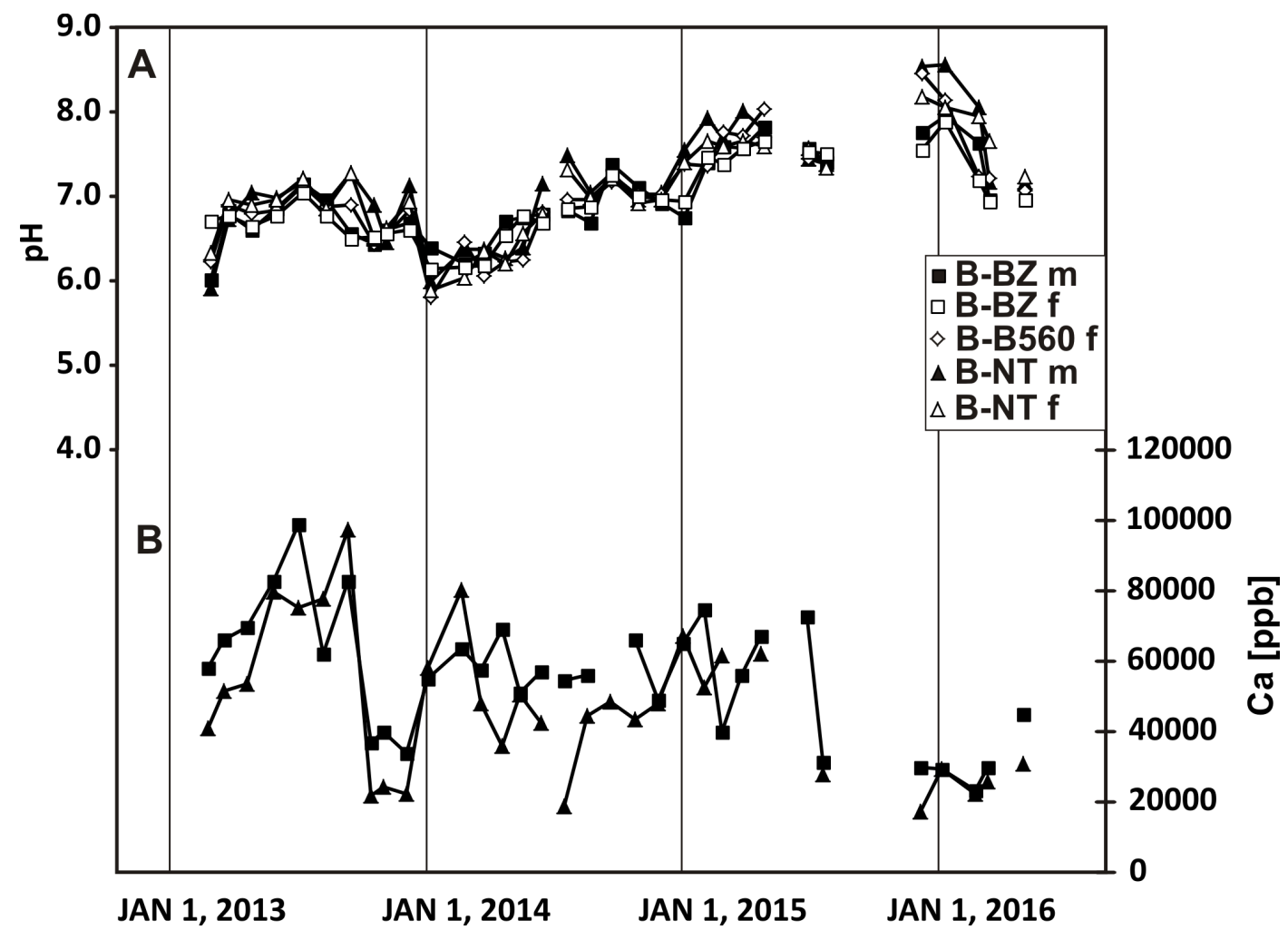

Fig. 4. Variation of $\mathrm{pH}(\mathrm{A})$ and $\mathrm{Ca}$ concentrations (B) measured in drip water at the sites in Béke Cave (B-NT $\mathrm{m}$ $=$ monthly drip water at Nagy-tufa; B-NT $f=$ fresh drip water at Nagy-tufa; B-560 $f=$ fresh drip water at the site of 560, B-BZ m = monthly drip water at Buzogány Hall; B-BZ f = fresh drip water at Buzogány Hall).

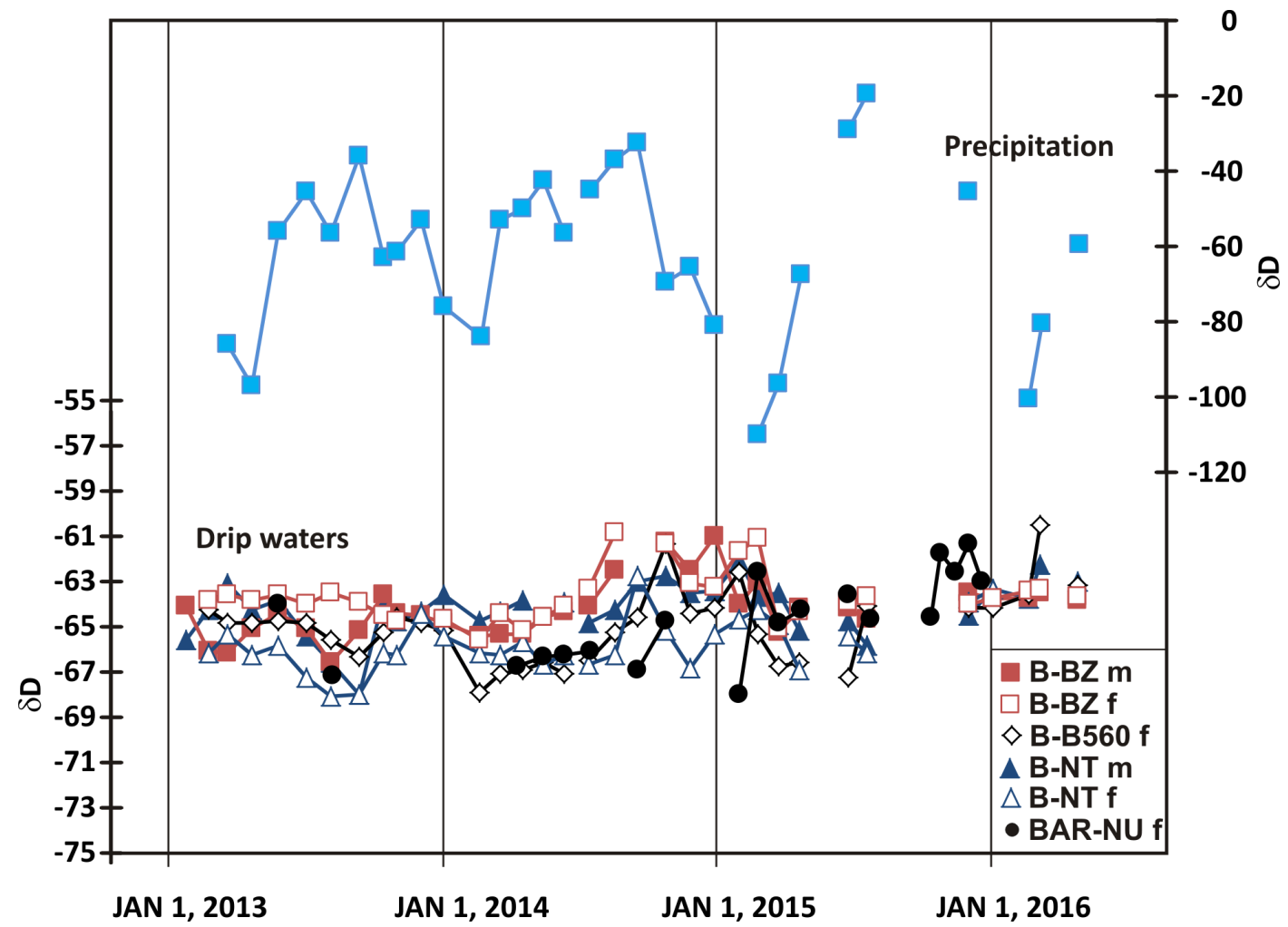

Fig. 5. $\delta \mathrm{D}$ values of precipitation and the drip water at the studied sits in Béke Cave (B-NT $m=$ monthly drip water at Nagy-tufa; B-NT $f=$ fresh drip water at Nagy-tufa; B-560 $f=$ fresh drip water at the site of 560, B-BZ $m=$ monthly drip water at Buzogány Hall; B-BZ $f=$ fresh drip water at Buzogány Hall) and in Baradla Cave (BAR-NU $f=$ fresh drip water at Nehéz-út). 


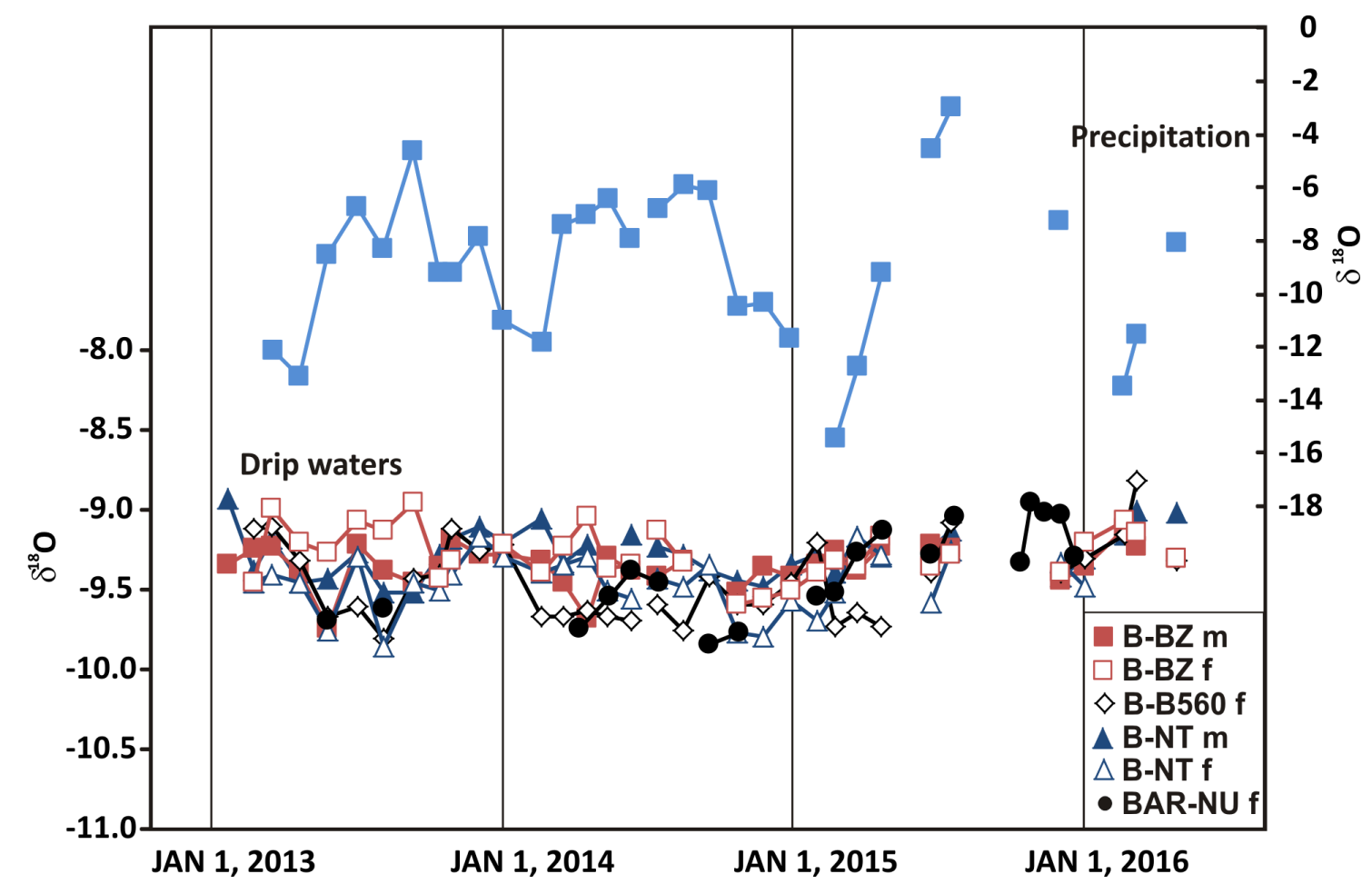

Fig. 6. $\delta^{18} \mathrm{O}$ values of precipitation and the drip water at the studied sites in Béke Cave (B-NT $m=$ monthly drip water at Nagy-tufa; B-NT $f=$ fresh drip water at Nagy-tufa; B-560 $f=$ fresh drip water at the site of 560, B-BZ $m=$ monthly drip water at Buzogány Hall; B-BZ $f=$ fresh drip water at Buzogány Hall) and in Baradla Cave (BAR-NU $f=$ fresh drip water at Nehéz-út).

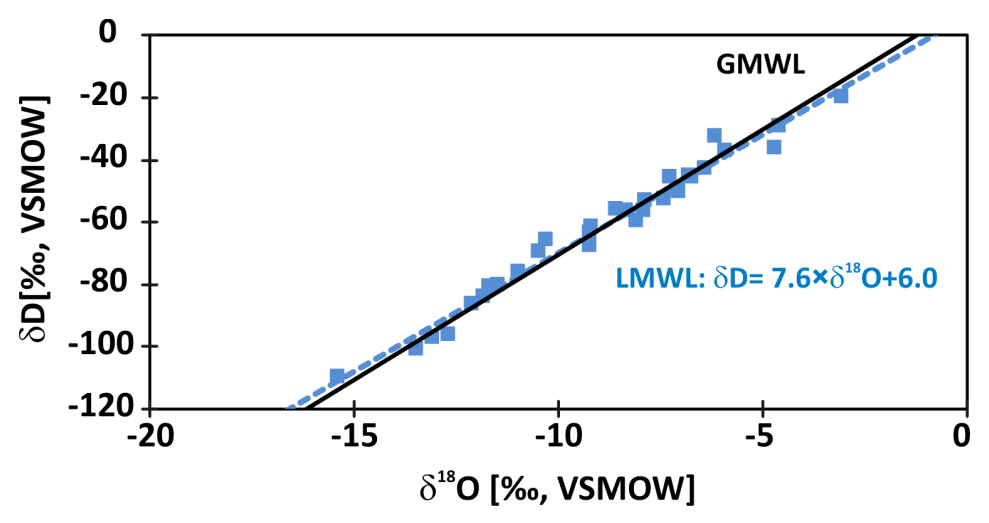

Fig. 7. The isotope composition of local precipitation. The equation of the local meteoric water line is $\delta D=7.6 \times \delta^{18} \mathrm{O}+6.0$ (blue dashed line). The global meteoric water line GMWL (Craig, 1971) is also shown.

\section{Stable isotope composition of fresh calcite precipitate}

In Buzogány Hall the light bulbs were collected four times representing periods of 5 to 14 months (Supplemental Table 8). The $\delta^{18} \mathrm{O}_{\mathrm{VPDB}}$ values of bulb carbonates ranged from $-7.4 \%$ o to $-6.4 \%$ o while the $\delta^{13} \mathrm{C}_{\mathrm{VPDB}}$ values varied between $-7.9 \%$ and $-11.3 \%$. The isotope compositions displayed variations between the dripping sites and within the individual bulb data sets (Supplemental Table 8, Fig. 8). Drip site I was characterized by higher drip rates while the drip site II showed a lower drip rate in general (Supplemental Table 7). The data from these two drip sites (bulbs $\mathrm{BZ}-1-\mathrm{BZ}-6)$ define positive $\delta^{18} \mathrm{O}-$ $\delta^{13} \mathrm{C}$ correlations (excluding bulb sample BZ-F9) with very similar slopes (3.4 and $3.5, R^{2}$ values are 0.9 and 0.6 , respectively) that fit the trend defined by all the data well (Fig. 8). Unfortunately, while taking the subsamples from these bulbs, it was not possible to determine the position where the drop of water hit the bulb first because the bulb moved due to the impact of the drops or because the shape of the carbonate precipitation was irregular. In addition, some samples were left for a relatively long time in the cave, thus the carbonates from different parts of the bulb probably represented distinct time periods of precipitation. Therefore, in these samples we could not test the criterion for isotopic equilibrium (i.e., the concomitant increase of $\delta^{13} \mathrm{C}$ and $\delta^{18} \mathrm{O}$ from the apex to the flank) defined by Hendy (1971).

The bulb sample BZ-F9 was collected when the other drip sites were inactive and the bulb's data set $(n=6)$ shows negligible $\delta^{13} \mathrm{C}$ and $\delta^{18} \mathrm{O}$ variations $( \pm 0.16$ and 0.02 , respectively) close to or within analytical precision, although the $\delta^{13} \mathrm{C}$ values displayed a clear rise (Supplemental Table 8) toward the flanks even within the small range (in $\delta^{18} \mathrm{O}$ values do not show concomitant change with $\delta^{13} \mathrm{C}$ values).

\section{${ }^{14} \mathrm{C}$ activity in modern calcite precipitates}

The ${ }^{14} \mathrm{C}$ activity of the fresh calcite precipitates collected at B-BZ site was measured (Supplemental Table 9) and the corresponding dead carbon proportion (dcp) values were calculated to achieve the actual atmospheric ${ }^{14} \mathrm{C}$ activity. Two samples displayed lower values $(73 \mathrm{pMC})$, which correspond to a relatively large dead carbon contribution ( 28.4\% dcp); while another sample showed greater values (98.5 pMC), which correspond to a lower dead carbon contribution (3.9\% dcp).

\section{${ }^{14} \mathrm{C}$ activity of drip waters}

The ${ }^{14} \mathrm{C}$ activity of the drip waters collected at BARNU site was analyzed (Supplemental Table 10). The results showed moderate variation in ${ }^{14} \mathrm{C}$ activity ranging from $83 \mathrm{pMC}$ to $101 \mathrm{pMC}$. 


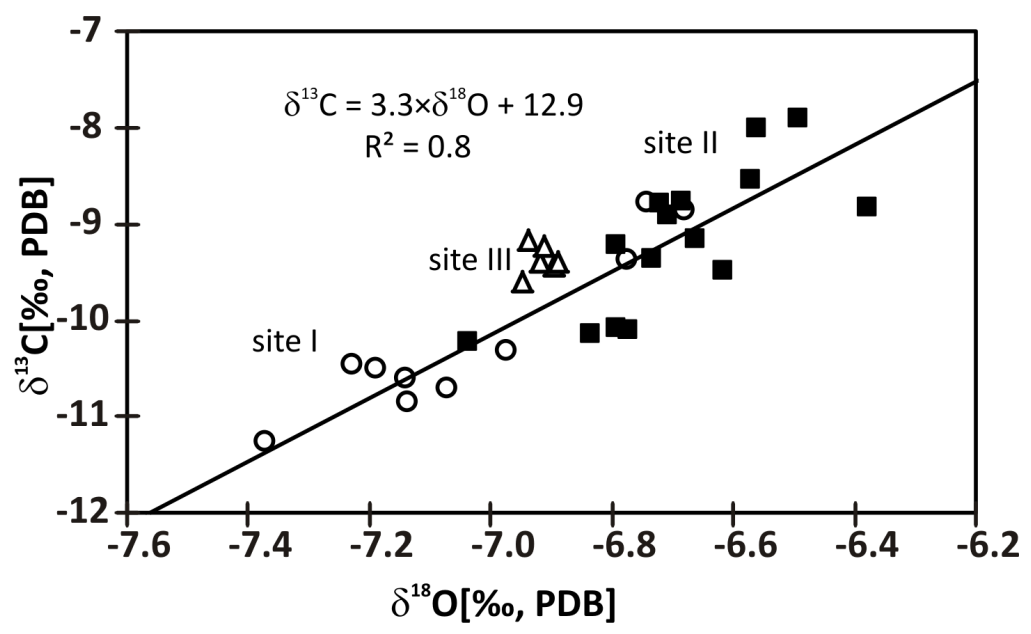

Fig. 8. Stable carbon and oxygen isotope compositions of calcite deposited on light bulbs in the Buzogány Hall. The three dripping sites are shown by different marks (site I (open circle): BZ-F1, BZ-F4, BZ-F-6; site II (black square): BZ-F2; BZ-F3, BZ-F5; site III (open triangle): BZ-F9).

\section{DISCUSSION}

\section{Relationship between $\delta^{18} \mathrm{O}$ of precipitation and temperature}

The stable isotope composition of precipitation, and hence the composition of the infiltrating water which fed the stalagmite, can be influenced by many factors and controls (Dansgaard, 1964; Rozanski et al., 1993; Lachniet et al., 2009). The six most important factors are: 1) moisture source, 2) temperature, 3) altitude, 4) the continental, 5) amount and 6) seasonal effects. The empirical correlations between these controls and the stable isotope compositions of precipitation are often used to interpret the stable isotope variability in speleothems (e.g., Mangini et al., 2005). Among these controls it is probably temperature, seasonal distribution of precipitation and moisture source and its changes that have the most significant impact on the stable isotope composition of the infiltrating water and hence the drip water in the studied area.

The correlation of stable isotope compositions of precipitation with temperature has long been known (Craig, 1961; Dansgaard, 1964) and it is used to calculate paleotemperature changes. However, the slope of precipitation $\delta^{18} \mathrm{O}$ versus temperature shows temporal/spatial variation and also depends on the method used to calculate temperature (Kohn \& Welker, 2005). Long term stable isotope compositions of precipitation have been reported only from Debrecen in Hungary (Vodila et al., 2011). This database was used to constrain the relationship between $\delta^{18} \mathrm{O}$ of precipitation and temperature for Debrecen. There, the observed slope of $\delta^{18} \mathrm{O}-\mathrm{T}$ function for the whole sampling period was $\sim 0.32 \% \circ /{ }^{\circ} \mathrm{C}$. However, if only the rainy days were considered for the temperature calculation a slope with a value of $\sim 0.37 \%$ o $/{ }^{\circ} \mathrm{C}$ was obtained. For the northern part of the Carpathians, Holko et al. (2012) reported variable values (0.19-0.41) for the slope of the $\delta^{18} \mathrm{O}-\mathrm{T}$ relationship. At the stations (Chopok \& Milhostov) closest to the studied caves, here values of $0.19 \% \circ /{ }^{\circ} \mathrm{C}$ and $0.28 \%$ o $/{ }^{\circ} \mathrm{C}$ were found. Our results $\left(0.33 \% \circ /{ }^{\circ} \mathrm{C} ; \mathrm{R}^{2}=0.64\right)$ agree well with these values and with the value of $0.31 \% \circ /{ }^{\circ} \mathrm{C}$ characteristic of the Northern Hemisphere (Rozanski et al., 1993).
In addition, we have also calculated the slope of $\delta \mathrm{D}-\mathrm{T}$ relationship $\left(2.5 \% \mathrm{o} /{ }^{\circ} \mathrm{C} ; \mathrm{R}^{2}=0.61\right)$ as number of the publications presenting $\delta \mathrm{D}$ of inclusion-hosted water is increasing, thus present knowledge on $\delta \mathrm{D}-\mathrm{T}$ correlation would provide additional constrain to interpret the fluid inclusion data. In summary, it seems that one of the major factors that controls the stable isotopic composition of precipitation is temperature. Thus, it is important to consider the temperature changes during the interpretation of stable isotope variability of the speleothems collected these sites.

Moreover, it should be noted that changes in the contribution of different moisture sources could also have significant influence on the stable isotope composition of precipitation and speleothems (e.g., Breitenbach et al., 2010). Hungary and hence the studied site receive precipitation originating from different sources (Bottyán et al., 2013, 2017; Czuppon et al., 2017). Bottyán et al. (2017) and Czuppon et al. (2017) showed that the precipitation derived from different moisture sources are characterized by a distinct stable isotope composition, resulting in a detectable influence on the stable isotopic composition of precipitation in Hungary. Thus, it is also necessary to consider moisture source changes for the interpretation of the stable isotope data of speleothems.

\section{Relationship between drip water and precipitation}

The isotopic compositions of drip and stream waters show constant and similar values $\left(\delta_{\mathrm{AVERAGE}}=\right.$ $-64.6 \pm 1.4 \%$ o and $\delta^{18} \mathrm{O}_{\text {AVERAGE }}=-9.40 \pm 0.20 \%$ o) at every site across the studied period in both the Béke and Baradla Caves. These values are more negative than the amount-weighted stable isotope composition of annual precipitation $\left(\delta D_{\text {AVERAGE }}=-62.3 \%\right.$ ond $\delta^{18} \mathrm{O}_{\text {AVERAGE }}=-9.09 \%$ o) suggesting a greater contribution from precipitation in cold months (winter). Although the amount of precipitation is greater in summer (Fig. 3), the calculated evapotranspiration is also larger in these months resulting in a reduction in the amount of the infiltrating water. Thus, the reason for the greater contribution of winter precipitation is the greater evapotranspiration in summer which results in a loss of part of the precipitation during warm months. By calculating the infiltration-weighted stable isotope composition of annual precipitation we obtained similar values $\left(\delta D_{\text {infiltration weighted prec. }}=-64.2 \%\right.$ o and $\delta^{18} \mathrm{O}_{\text {infiltration weighted prec. }}=-9.34 \%$ o) to those observed in drip waters. The stable isotope compositions of cave waters do not reveal clear seasonality indicating a well-mixed aquifer above the cave. The lack of seasonality in the $\delta \mathrm{D}$ and $\delta^{18} \mathrm{O}$ values implies that the residence time is more than one year and the signal transferred through the stable isotope composition of drip water to the speleothem will likely record interannual climate trends, but not seasonal dynamics.

The residence time of the water which feeds the drip water has been determined in relatively few caves by the ${ }^{3} \mathrm{H}-{ }^{3} \mathrm{He}$ dating method, which is one of 
the most promising methods to determine the "age" of the drip water. Most recently, Kluge et al. (2010) used this method to calculate the residence time of the drip water in Bunker Cave, which was around 2-3 years despite of the relative thin overlying rock (15-30 m). This result was further supported by longterm monitoring of stable isotopes of drip water by Riechelmann et al. (2017) who obtained 2.5 years. Above the studied sites (Béke and Baradla caves), the thickness of the overburden rock is more than 50 $100 \mathrm{~m}$. Therefore, it is reasonable to assume that the residence time of the drip water in the studied area is several years. Based on tritium measurements, Molnár et al. (2007) also suggested that the residence time of the drip water in the Baradla Cave is more than 1-2 years.

\section{Cave climate and water chemistry}

Many studies have shown that the concentration of $\mathrm{CO}_{2}$ in cave air and its seasonality are one of the most important variables that can influence calcite precipitation within the cave and hence chemical and isotopic composition, and the fabric of the forming speleothems (Spötl et al., 2005; Mattey et al., 2008, Boch et al., 2011; Sherwin and Baldini, 2011; Breitenbach et al., 2015). The variability of $\mathrm{CO}_{2}$ concentration in a cave strongly depends on the ventilation dynamics. The strength and the timing of the ventilation are controlled by the temperature contrast between the cave interior and the outside, synoptic scale atmospheric pressure and wind conditions as well as cave morphology (Mattey et al., 2008). These variables can change from cave to cave; thus different caves can be characterized by variable ventilation dynamics and $\mathrm{CO}_{2}$ concentrations. In general, it is expected that lower cave air $\mathrm{pCO}_{2}$ (either occurring in winter as in St. Michael's Cave on the Gibraltar peninsula (Mattey et al., 2008) or in summer like in the Obir Cave in Austria (Spötl et al., 2005) will cause more rapid degassing and higher calcite supersaturation, and hence rapid calcite precipitation that appears to affect the fabric, trace element and isotopic composition of the deposit (Mattey et al., 2008).

In both studied caves, $\mathrm{pCO}_{2}$ was extremely high during summer (Fig. 2., 30,000 ppm in Béke Cave and 4,200 ppm in Baradla Cave) and moderately high during winter (Fig. 2., 1,500 ppm in Béke Cave and $1,600 \mathrm{ppm}$ in Baradla Cave) compared with other caves (e.g., Obir Cave 500-1500 ppm, Spötl et al., 2005; Bunker Cave: 850-1,200 ppm, Riechelmann et al., 2011; Cueva de Asiul: 360-2,090 ppm, Smith et al., 2016). It is reasonable to assume that this seasonal variation of $\mathrm{pCO}_{2}$ will have an effect on calcite precipitation rate (and hence its stable isotope composition) as greater $\mathrm{CO}_{2}$ concentrations may retain the carbonate formation. Thus, it is expected that calcite precipitation is enhanced during winter when cave air $\mathrm{pCO}_{2}$ is drastically lowered.

In addition, it seems that the drip water chemistry (and the composition of calcite precipitates) is influenced by the hydrological condition of the epikarst. The beginning of our monitoring work (especially in the first half of 2013) was characterized by extreme wet conditions whereas the following period through to the beginning of 2016 was drier. Especially the winter months were relatively dry when the drip rates at every studied site decreased (Supplemental Table 7). During these drier periods, the karst was less filled with percolating water, resulting in a greater possibility for degassing, which could cause calcite precipitation to occur before reaching the cave chamber where the drip waters were collected. This process is called Prior Calcite Precipitation (PCP) and has a significant effect on the isotopic composition and chemistry of the drip water as PCP removes ions from the infiltrating water (Fairchild et al., 2000; 2006; Tremaine \& Froelich, 2013; Sherwin \& Baldini, 2011, and Wong et al., 2011). The negative relationship between $\mathrm{Ca}^{2+}$ concentration and the $\mathrm{Mg} / \mathrm{Ca}$ ratio, as well as the positive correlation between the $\mathrm{Mg} / \mathrm{Ca}$ and $\mathrm{Sr} / \mathrm{Ca}$ ratios observed in the drip water collected at Buzogány Hall and Nagy-tufa site (Béke Cave) are indicative of this PCP process (Fig. 9). Moreover, the concurrent increase of $\mathrm{Mg} / \mathrm{Ca}$ and $\mathrm{Sr} / \mathrm{Ca}$ ratios in drip water can also be explained by prolonged water-rock interaction, which favors incongruent carbonate dissolution (e.g., McGillen \& Fairchild, 2005; Borsato et al., 2016). Shorter water-rock interaction favors preferential dissolution of $\mathrm{Ca}$ with respect to $\mathrm{Mg}$ and $\mathrm{Sr}$, while longer residence times induce more dissolution of $\mathrm{Mg}$ and Sr. As the host rock is not pure calcite but also contains dolomitic layers (i.e., Guttenstein Limestone; e.g., Hips, 2003), the different residence times (i.e., different degrees of water-rock interaction) may lead to incongruent carbonate dissolution. To deconvolve the processes responsible for the correlation between $\mathrm{Mg} / \mathrm{Ca}$ and $\mathrm{Sr} / \mathrm{Ca}$, Borsato et al. (2016) suggested the use of additional element ratios which are not sourced from the carbonate host rock. In our case we could use $\mathrm{Si} / \mathrm{Ca}$ and $\mathrm{Na} / \mathrm{Ca}$ in drip waters to complement $\mathrm{Mg} / \mathrm{Ca}$ and $\mathrm{Sr} / \mathrm{Ca}$ (Fig. 10). As Si and $\mathrm{Na}$ are derived from siliciclastic minerals from the soil zone or anthrophonic activity (e.g., feeding animals salt during winter time) rather than from carbonate host rock, the correlation between $\mathrm{Mg} / \mathrm{Ca}$ and both $\mathrm{Si} / \mathrm{Ca}$ and $\mathrm{Na} / \mathrm{Ca}$ indicates that $\mathrm{PCP}$ plays a major role in producing the observed systematics rather than incongruent carbonate dissolution.

\section{Signs of kinetic fractionation and their consequences}

A linear, positive $\delta^{18} \mathrm{O}-\delta^{13} \mathrm{C}$ correlation was found for the light bulb samples $\left(\delta^{13} \mathrm{C}=3.3 \times \delta^{18} \mathrm{O}+12.9\right.$, $\mathrm{R}^{2}=0.8$; Fig. 8) which were collected in the Buzogány Hall, Béke Cave (Supplemental Table 8). The trend is actually composed of the results of several analyses of carbonate subsamples from the bulbs which were placed in the cave (except sample BZ-F9). Only in the case of BZ-F9 sample was it possible to exactly define the apex where a concomitant increase of $\delta^{13} \mathrm{C}$ and $\delta^{18} \mathrm{O}$ was not observed. In the case of other samples the apex could not be determined (see more details in the results); thus it was not possible to provide evidence for the classical Hendy test criterion (Hendy, 1971). Moreover, the observed trend has a similar slope (3.3) 


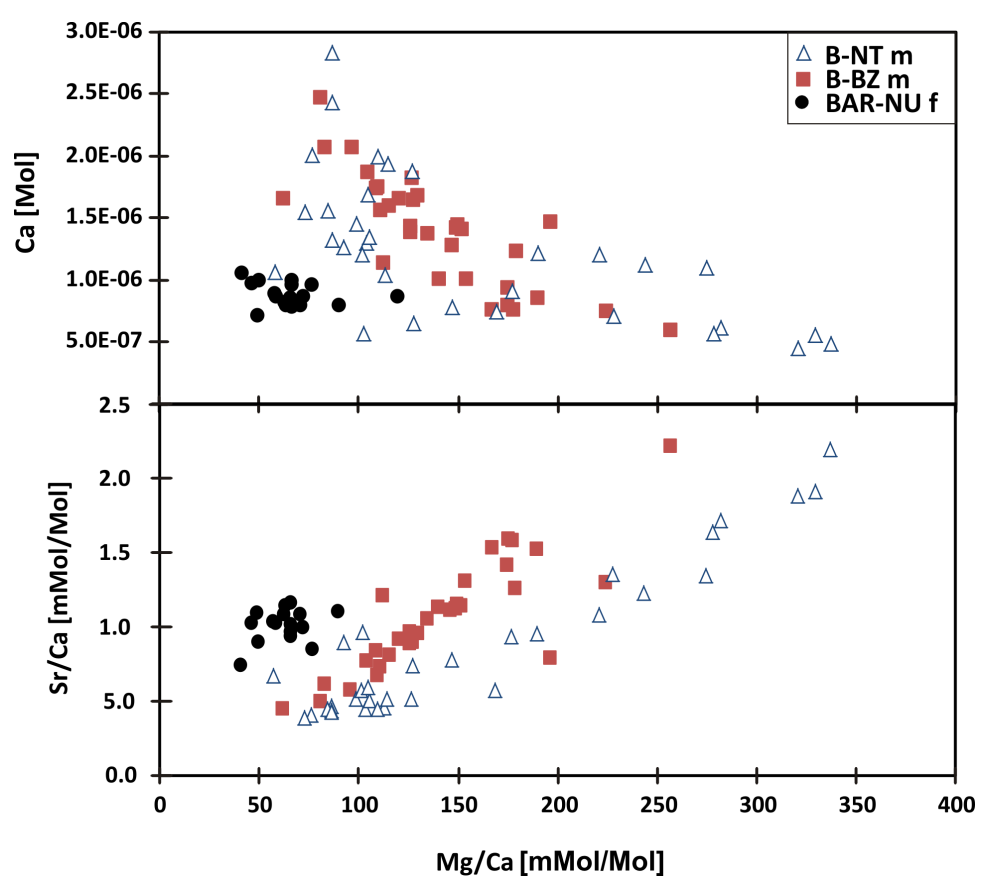

Fig. 9. $\mathrm{Ca}^{2+}$ concentration vs. $\mathrm{Mg} / \mathrm{Ca}$ ratio $(\mathrm{A})$ and $\mathrm{Sr} / \mathrm{Mg}$ vs $\mathrm{Mg} / \mathrm{Ca}$ ratios (B) for the different drip sites (B-NT $m=$ monthly drip water at Nagy-tufa, Béke Cave; B-BZ $m$ = monthly drip water at Buzogány Hall, Béke Cave; BAR-NU $f=$ fresh drip water at Nehéz-út, Baradla Cave).

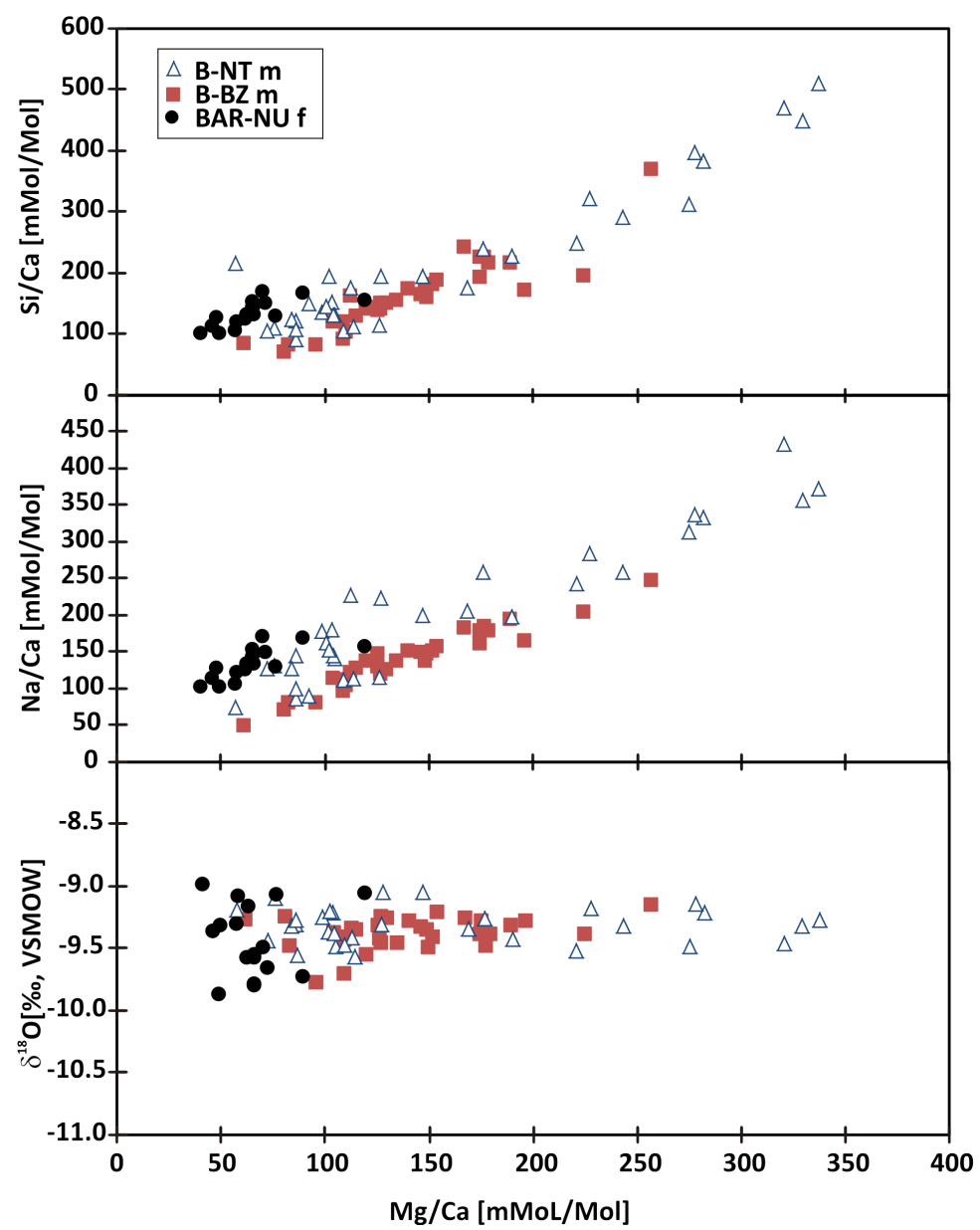

Fig. 10. The $\mathrm{Mg} / \mathrm{Ca}$ ratios are plotted against $\mathrm{Si} / \mathrm{Ca}$ ratios (A), Na/Ca ratios (B) and $\delta^{18} \mathrm{O}$ for the different drip sites (B-NT $\mathrm{m}=$ monthly drip water at Nagy-tufa, Béke Cave; B-BZ m = monthly drip water at Buzogány Hall, Béke Cave; BAR$\mathrm{NU} f=$ fresh drip water at Nehéz-út, Baradla Cave).

to the kinetically fractionated calcite trend (slope $~ 3.9$ ) defined by Mickler et al. (2006) suggesting that kinetic fractionation played a significant role to produce the observed variation. Tremaine et al. (2011) showed that ventilation induced kinetic fractionation and rapid calcite precipitation together can have a significant effect on carbon and oxygen isotopic compositions, driving $\delta^{13} \mathrm{C}$ and $\delta^{18} \mathrm{O}$ to more positive values. In Béke Cave, $\mathrm{pCO}_{2}$ was extremely high during the whole period; especially in summer when the $\mathrm{CO}_{2}$ concentration reached 35,000 ppm. During winter it decreased drastically (3,000-1,500 ppm) but the observed $\mathrm{pCO}_{2}$ values were still high compared to several other caves (e.g., 850-1,200 ppm in Bunker Cave, Riechelmann et al., 2011). This high $\mathrm{CO}_{2}$ concentration during the whole year implies that ventilation did not play a significant role to remove $\mathrm{CO}_{2}$ from the cave during the monitoring period. The carbonates from this cave (BZ-F9 samples, Fig. 8. and Supplemental Table 8) that precipitated in winter do not show significant isotopic enrichments or shifts (i.e., kinetic fractionation), even though a greater influence of ventilation would be expected during that time. Thus, it can be argued that ventilation induced kinetic fractionation probably had only minor effect on the isotopic composition of the samples in Béke Cave.

Alternatively, the positive shift in $\delta^{18} \mathrm{O}$ and $\delta^{13} \mathrm{C}$ values can result from prolonged residence time of the thin solution film on the bulb (i.e., stalagmite surface, Mickler et al., 2006; Mühlinghaus et al., 2007, 2009; Scholz et al., 2009). Longer residence times of the fluid on the bulb or stalagmite surface occur when the drip rate is low. Riechelmann et al. (2013) documented this relationship with field observations in Bunker Cave (Germany). Although there was no continuous instrumental drip rate counting at Buzogány Hall in Béke cave high drip rates were observed during field work at the beginning of the monitoring period (beginning of 2013) with a clear and gradual decrease during the winter months. Relatively drier conditions were also characteristic for the period from October 2014 until January 2016 within both Béke and Baradla caves. During this period the lower drip rates likely resulted in a prolonged residence time of the fluid on the bulb, leading to elevated $\delta^{13} \mathrm{C}$ and $\delta^{18} \mathrm{O}$ values. Additionally, PCP, which was evident from the elemental compositions of the drip waters collected at B-BZ site (and also at B-NT site), also indicates periods with low discharge during the monitoring campaign.

The differences found in the isotopic compositions between sites I and II are most likely also related to different drip rates (Supplemental Table 7). Drip site II tended to be more enriched in ${ }^{16} \mathrm{O}$ showing more positive $\delta^{18} \mathrm{O}$ values. It is thus also related to kinetic fractionation and the prolonged residence time of drip water on the bulb. Similar differences between drip sites were also observed in Bunker Cave (Riechelmann et al., 2013). In addition, ${ }^{14} \mathrm{C}$ activity values showed differences between two sides; although we should note that only three of the bulb carbonate samples were analyzed for their ${ }^{14} \mathrm{C}$ activity values, thus this data set is probably not robust enough. Based on these three analyses it is apparent that the carbonate precipitates at 
drip site II (BZ-F2 and BZ-F3, Supplemental Table 9) had lower ${ }^{14} \mathrm{C}$ activity values (73 $\left.\mathrm{pMC}\right)$, indicating more dead carbon contribution ( $28 \%$ dcp) relative to drip site I (99 pMC and 4\% dcp). This difference is also probably related to the distinct drip rate and variability of infiltration. Slower infiltration speed and longer residence time would lead to enhanced degassing and PCP and higher dcp values as observed for drip site II.

\section{Exploration of equilibrium fractionation}

Although recently many studies proved that kinetically altered speleothem-based isotope records can provide an excellent data set to reconstruct environmental/climatic changes in the past (e.g., Kennett et al., 2012; Tan et al., 2015; Cheng et al., 2016), in general, stalagmites with a close-to-equilibrium oxygen isotope composition should be selected for paleoclimate studies (e.g., Bar-Matthews et al., 1996; Serefiddin et al., 2004; Fuller et al., 2008) especially with the aim to calculate past temperatures. The usual procedure for identifying the equilibrium condition (apart from Hendy test, simultaneous records) is the comparison of measured isotopic composition with the calculated values obtained using temperature and water composition data and an equation that best describes equilibrium fractionation. In the last few decades numerous equations have been published including experimental, theoretical and empirical investigations (Kim \& O'Neil, 1997; Coplen, 2007; Horita \& Clayton, 2007; Chacko \& Deines, 2008; Dietzel et al., 2009; Demény et al., 2010; Tremaine et al., 2011; Gabitov et al., 2012; Kele et al., 2015). Several studies on inorganic carbonates demonstrated that the $\delta^{18} \mathrm{O}$ of naturally precipitated carbonates (e.g., speleothems) show systematically higher values than the $\delta^{18} \mathrm{O}$ of laboratory-grown calcite (Coplen, 2007; Demény et al., 2010; Tremaine et al., 2011). Thus, the equations obtained by studying natural samples (i.e., empirical approach: Coplen, 2007; Tremaine et al., 2011) are increasingly used to obtain reliable temperature data (e.g., Meckler et al., 2015) instead of equations obtained using experimental results and theoretical calculations.

To characterize the carbonate precipitation of the studied caves and find the best equation to calculate speleothem-based temperature, we selected isotope analyses of different carbonates which formed in the Béke and Baradla Caves. The bulb carbonates from Béke Cave (collected at sites I and II in Buzogány Hall) recorded evidence of kinetic fractionation, hence only the least affected samples were selected for further evaluation. Bulb sample BZ-F1 provided the lowest $\delta^{13} \mathrm{C}$ and $\delta^{18} \mathrm{O}$ values among the bulb carbonates, whereas sample BZ-F9 was selected on the basis of very small internal variation and hence lower influence of kinetic fractionation. Monitoring provided temperature, $\mathrm{pH}$ and $\delta^{18} \mathrm{O}_{\text {water }}$ values from which winter values were chosen as the majority of the carbonate likely precipitated during that time. $\delta^{18} \mathrm{O}_{\text {carbonate }}$ values of flowstone samples at the Nagy-tufa site (in Béke Cave) and at the Havasok flowstone in the Baradla Cave closest to the water discharge points and average temperature, $\mathrm{pH}$ and $\delta^{18} \mathrm{O}_{\mathrm{w}}$ values were used in the calculations. Finally, $\delta^{18} \mathrm{O}_{\text {carbonate }}$ data gathered from the stalagmite surface and the youngest laminas (within $\sim 3 \mathrm{~mm}$ from the top, representing 10 years from 1999 to 2010) of an actively growing stalagmite from Nehéz-út site in Baradla Cave (NU-2, Demény et al., 2017) were also used in the evaluation. As, by definition, the fractionation factor $\mathrm{a}$ is the ratio of the isotope ratios ${ }^{18} \mathrm{O} /{ }^{16} \mathrm{O}_{\text {carbonate }}$ and ${ }^{18} \mathrm{O} /{ }^{16} \mathrm{O}_{\text {water }}$ and $\left.\delta^{18} \mathrm{O}=\left({ }^{18} \mathrm{O} /{ }^{16} \mathrm{O}\right) /\left({ }^{18} \mathrm{O} /{ }^{16} \mathrm{O}_{\text {standard }}\right)-1\right) \times 1000$, the oxygen isotope fractionation values (1000/nna) are given by the equation $\mathrm{a}=\left(1000+\delta^{18} \mathrm{O}_{\text {carbonate, }}\right.$ -vsmow) / $\left(1000+\delta^{18} \mathrm{O}_{\text {water, }}\right.$-vsmow $)$. The $1000 \cdot \ln$ a values depend on formation temperature as described by the general equation: $1000 \cdot \ln \alpha=1000 \cdot \mathrm{A} / \mathrm{T}-\mathrm{B}$, where the constants A and B are 17.4 and 28.6 (Coplen, 2007), or 16.1 and 24.6 (Tremaine et al., 2011), respectively.

The calculated values for the farmed calcite precipitates and speleothems are plotted in Fig. 11 along with published equilibrium regressions. Most of the data scatter around the Coplen (2007) and the Tremaine et al. (2011) equilibrium regressions. This scatter may partially derive from error propagation of analytical precision, but primary natural factors (apart from those mentioned in the previous sections) may also play a role. Watkins et al. (2014) presented a comprehensive evaluation of fractionation processes that led to deviations from "equilibrium" values. One of the main factors is the $\mathrm{pH}$ value of the host solution, as the solution $\mathrm{pH}$ determines the relative concentrations of dissolved $\mathrm{C}$ species $\left(\mathrm{CO}_{2(\mathrm{aq})}, \mathrm{CO}_{3}{ }^{2-}\right.$, and $\left.\mathrm{HCO}_{3}{ }^{-}\right)$that have different compound $-\mathrm{H}_{2} \mathrm{O}$ oxygen isotope fractionation values. Hence the deviations of measured 1000-1na values from those calculated using the Tremaine et al. (2011) equation were plotted as a function of $\mathrm{pH}$ (Fig. 12). Similar data gathered from publications that reported $\mathrm{pH}$ values together with temperature and carbonate and water isotopic compositions are also shown in Fig. 12. The broadly negative relationship

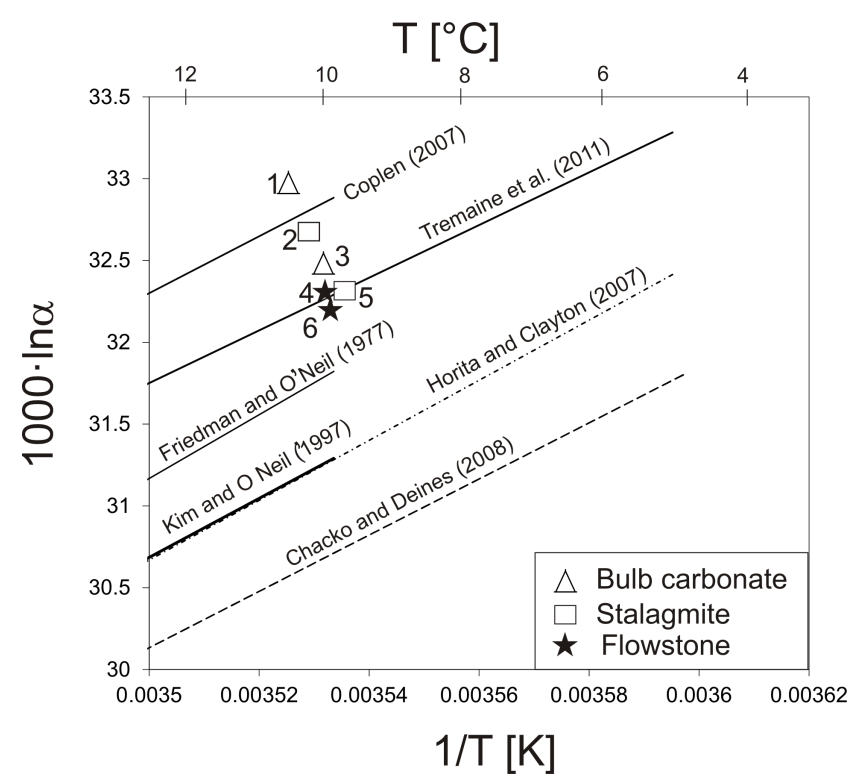

Fig. 11. Calcite-water $1000 \cdot \ln \alpha$ values vs. $1 / \mathrm{T}$ (in ${ }^{\circ} \mathrm{K}$ ) measured for speleothem samples from the Baradla and Béke caves and selected published curves. 1) Buzogány, bulb, sample F9; 2( NU-2 stalagmite, topmost $3 \mathrm{~mm}$ average; 3) Buzogány, bulb, sample $\mathrm{F} 1$, lowest $\delta^{18} \mathrm{O}$; 4) Nagy-tufa, closest to water discharge; 5) NU-2 stalagmite, surface sample; 6) Havasok flowstone, close to the water discharge point. 


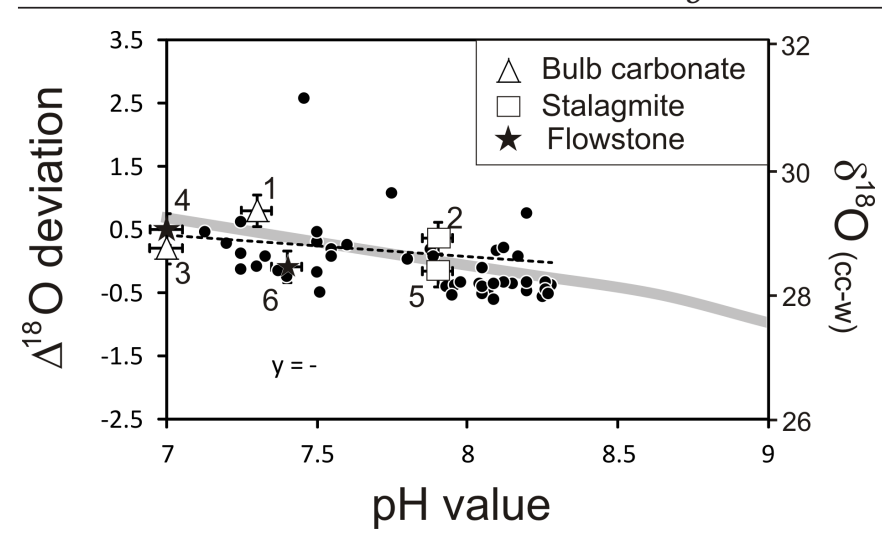

Fig. 12. Deviation of measured carbonate-water oxygen isotope fractionation from the equation of Tremaine et al. (2011) as a function of $\mathrm{pH}$ value of drip water $\left(\Delta^{18} \mathrm{O}\right.$ deviation, left vertical axis). Black filled circles: published data (Daeron et al., 2011; Tremaine et al., 2011; Moreno et al., 2014; Van Rampelbergh et al., 2014).Grey line: calcitewater (cc-w) oxygen isotope fractionation $\left(\delta^{18} \mathrm{O}_{(\mathrm{cc}-\mathrm{w})}\right.$, right vertical axis) as a function of $\mathrm{pH}$ calculated by Watkins et al. (2014) for $25^{\circ} \mathrm{C}$. Uncertainties of sample points are based on the analytical uncertainties of $\mathrm{pH}$ and $\delta^{18} \mathrm{O}$ analyses. Dashed line shows linear regression for the samples studied in this paper $(R=-0.31)$. Sample numbers as in Fig. 11.

between the fractionation deviation (from Tremaine et al., equation) and $\mathrm{pH}$ (shown by the linear regression line in Fig. $12 ; \Delta^{18} \mathrm{O}=-0.34 \cdot \mathrm{pH}+2.8, \mathrm{R}=0.31$ ) agrees well with the results of theoretical calculations (grey line in Fig. 12) of Watkins et al. (2014), suggesting that the observed data scatter can be partly explained by variations in drip water $\mathrm{pH}$.

In summary, based on the recent observations it can be concluded that the speleothems from Béke and Baradla Caves are suitable for paleoclimate research as they can record multiannual climate trends, wet and dry periods inferred from concomitant stable and trace element measurements. In addition, it was found that the Tremaine et al. (2011) and Coplen (2007) equations best describe the recent carbonate fractionation in the studied caves, thus these equations are recommended for performing paleotemperature calculations.

\section{CONCLUSIONS}

The extensive monitoring campaign performed in the Baradla and Béke caves (NE Hungary) suggests the following:

- The stable isotope composition of drip waters at each site studied in both caves showed the same values with no significant variability (no seasonality) during the entire monitoring campaign, indicating a well-mixed aquifer with a relatively long residence time in the epikarst (more than one year). This finding suggests that $\delta D$ and $\delta^{18} O$ values of drip waters can record inter-annual climate trends.

- The isotopic composition of the drip water is more negative than the amount-weighted annual precipitation value, indicating more contribution from winter precipitation.

- The $\mathrm{CO}_{2}$ concentration in both caves shows seasonality; the summer is characterized by high values while winter by low values, affecting calcite precipitation.

- The chemistry of drip waters shows great variability in the studied period. The correlation of $\mathrm{Mg} / \mathrm{Ca}$ ratios with $\mathrm{Sr} / \mathrm{Ca}, \mathrm{Na} / \mathrm{Ca}$, and $\mathrm{Si} / \mathrm{Ca}$ suggest Prior Calcite Precipitation (PCP) rather than incongruent dissolution of host carbonates. The PCP likely took place when infiltration was reduced (during dry periods). Moreover, it should be emphasized that these processes (PCP and reduced infiltration) do not affect the stable isotope composition of drip water unless significant evaporation takes place in the karst system.

- The carbon and oxygen isotopic composition of modern (in situ) carbonate precipitates shows good correlation indicating kinetic fractionation, which is likely related to the prolonged residence time of the thin solution film on the bulb surface.

- The measured carbonate-water oxygen isotope fractionation for the modern carbonate precipitates (which are less affected by kinetic fractionation) and for the top actively forming flowstones and speleothems can be mostly described by the equations published by Tremaine et al. (2011) and Coplen (2007) implying these equations should be used for paleotemperature calculations.

- Using all these pieces of information the main conclusion is that the speleothems from these caves seem to be suitable for recording multiannual winter biased climate trends. In addition, the concomitant stable isotope and trace element variations observed in the speleothems could provide evidence for dry and wet periods.

\section{ACKNOWLEDGEMENTS}

This research was financed by the Hungarian Scientific Research Fund (OTKA NK 101664 and $\mathrm{PD}$ 121387). The research was also supported by the European Union and the State of Hungary, cofinanced by the European Regional Development Fund in the project of GINOP-2.3.2-15-2016-00009 'ICER'. The János Bolyai Research Scholarship of the Hungarian Academy of Sciences financially supported György Czuppon's work. We thank Professor Bogdan P. Onac for the constructive editorial handling. We also thank the reviewers (Sebastian Breitenbach and two anonymous) for the valuable comments and suggestions that helped to improve the manuscript. We are also very grateful to Dr. Monica Handler and Iain Coulthard for improving the English of the manuscript.

\section{REFERENCES}

Bar-Matthews M., Ayalon A., Matthews A., Sass E. \& Halicz L., 1996 - Carbon and oxygen isotope study of the active water-carbonate system in a karstic Mediterranean cave: Implications for paleoclimate research in semiarid regions. Geochimica et Cosmochimica Acta, 60 (2): $337-$ 347. https://doi.org/10.1016/0016-7037(95)00395-9

Boch R. \& Spötl C., 2011 - Reconstructing palaeoprecipitation from an active cave flowstone. Journal of Quaternary Science, 26: 675-687. https://doi.org/10.1002/jqs.1490 Boch R., Spötl C. \& Frisia S., 2011 - Origin and palaeoenvironmental significance of lamination in stalagmites from Katerloch Cave, Austria. Sedimentology, 58: 508-531.

https://doi.org/10.1111/j.1365-3091.2010.01173.x 
Borsato A., Johnston V.E., Frisia S., Miorandi R. \& Corradini F., 2016 - Temperature and altitudinal influence on karst dripwater chemistry: Implications for regional-scale palaeoclimate reconstructions from speleothems. Geochimica et Cosmochimica Acta, 177: 275-297. https://doi.org/10.1016/j.gca.2015.11.043

Bottyán E., Czuppon Gy., Weidinger T., Haszpra L. \& Kármán K., 2013 - Determination of air moisture source region for precipitation in Hungary. Central European Geology, 56: 273.

Bottyán E., Czuppon Gy., Weidinger T., Haszpra L. \& Kármán K., 2017 - Moisture source diagnostics and isotope characteristics for precipitation in east Hungary: implications for their relationship. Hydrological Science Journal, 62 (12): 2049-2060.

https://doi.org/10.1080/02626667.2017.1358450

Breitenbach S.F.M., Adkins J.F., Meyer H. \& Marwan N., Krishna Kumar K. \& Haug G.H., 2010 - Strong in fluence of water vapor source dynamics on stable isotopes in precipitation observed in Southern Meghalaya, NE India. Earth and Planetary Science Letters, 292: 212-220. https://doi.org/10.1016/j.eps1.2010.01.038

Breitenbach S.F.M., Lechleitner F.A., Meyer H., Diengdoh G., Mattey D. \& Marwan N., 2015 - Cave ventilation and rainfall signals in dripwater in a monsoonal setting - a monitoring study from NE India. Chemical Geology, 402: 111-124.

https://doi.org/10.1016/j.chemgeo.2015.03.011

Chacko T. \& Deines P., 2008 - Theoretical calculation of oxygen isotopic fractionation factors in carbonate systems. Geochimica et Cosmochimica Acta, 72: 3642-3660. https://doi.org/10.1016/j.gca.2008.06.001

Cheng H., Spötl C., Breitenbach S.F:M., Sinha A., Wassenburg J.A., Jochum K.P., Cholz D., Li X., Yi L., Peng Y., Lv Y., Zhang P., Votintseva A., Loginov V., Ning Y., Kathayat G. \& Edwards R.L., 2016 - Climate variations of Central Asia on orbital to millennial timescales. Sciemntific Reports, 6: 36975. https://doi.org/10.1038/srep36975

Coplen T.B., 1996 - New guidelines for reporting stable hydrogen, carbon, and oxygen isotope-ratio data. Geochimica et Cosmochimica Acta, 60: 3359-3360. https://doi.org/10.1016/0016-7037(96)00263-3

Coplen T.B., 2007 - Calibration of the calcite-water oxygen-isotope geothermometer at Devils Hole, Nevada, a natural laboratory. Geochimica et Cosmochimica Acta, 71: 3948-3957.

https://doi.org/10.1016/j.gca.2007.05.028

Craig H., 1961 - Isotopic variations in meteoric waters. Science, 133: 1702-1703.

https://doi.org/10.1126/science.133.3465.1702

Czuppon Gy., Bottyán E., Haszpra L., Weidinger T. \& Kármán K., 2017 - Significance of the air moisture source on the stable isotope composition of the precipitation in Hungary. EGU General Assembly, Geophysical Research Abstracts, 19: 13458.

Daeron M., Guo W., Eiler J., Genty D., Blamart D., Boch R., Drysdale R. N., Maire R., Wainer K. \& Zanchetta G., $2011-{ }^{13} \mathrm{C}^{18} \mathrm{O}$ clumping in speleothems: Observations from natural caves and precipitation experiments. Geochimica Cosmochimica Acta, 75: 3303-3317. https://doi.org/10.1016/j.gca.2010.10.032

Dansgaard W., 1964 - Stable isotopes in precipitation. Tellus, 16: 436-468.

https://doi.org/10.3402/tellusa.v16i4.8993

Demény A., Németh A., Kern Z., Czuppon Gy., Molnár M., Leél-Össy Sz., Óvári M. \& Stieber J., 2017 - Recently forming stalagmites from the Baradla Cave and their suitability assessment for climate-proxy relationships. Central European Geology, 60 (1): 1-34.

https://doi.org/10.1556/24.60.2017.001
Demény A., Kele S. \& Siklósy Z., 2010 - Empirical equations for the temperature dependence of calcitewater oxygen isotope fractionation from 10 to $70{ }^{\circ} \mathrm{C}$. Rapid Communication in Mass Spectrometry, 24: 3521-3526. https://doi.org/10.1002/rcm.4799

Demény A., Czuppon Gy., Siklósy Z., Leél-Össy Sz., Lin K., Shen C-C. \& Gulyás K., 2013 - Mid-Holocene climate conditions and moisture source variations based on stable $H, C$ and $O$ isotope compositions of speleothems in Hungary. Quaternary International, 293: 150-156. https://doi.org/10.1016/j.quaint.2012.05.035

Dietzel M., Tang J., Leis A. \& Köhler S.J., 2009 Oxygen isotopic fractionation during inorganic calcite precipitation - Effects of temperature, precipitation rate and $\mathrm{pH}$. Chemical Geology, 268: 107-115. https://doi.org/10.1016/j.chemgeo.2009.07.015

Fairchild I.J., Borsato A., Tooth A.F., Frisia S., Hawkesworth C.J., Huang Y.M., McDermott F. \& Spiro B., 2000 - Controls on trace element $(\mathrm{Sr}-\mathrm{Mg})$ compositions of carbonate cave waters: implications for speleothem climatic records. Chemical Geology, 166: 255-269. https://doi.org/10.1016/S0009-2541(99)00216-8

Fairchild I.J., Smith C.L., Baker A., Fuller L., Spötl C., Mattey D., McDermott F. \& E.I.M.F., 2006 Modification and preservation of environmental signals in speleothems. Earth Science Reviews, 75: 105-153. https://doi.org/10.1016/j.earscirev.2005.08.003

Fairchild I.J., Baker A., 2012 - Speleothem science: From process to past environments. Wiley-Blackwell, $450 \mathrm{p}$. https://doi.org/10.1002/9781444361094

Fuller L., Baker A., Fairchild I.J., Spötl C., Marca-Bell A., Rowe P. \& Dennis P.F., 2008 - Isotope hydrology of dripwaters in a Scottish cave and implications for stalagmite palaeoclimate research. Hydrology and Earth System Sciences, 5 (2): 547-577.

https://doi.org/10.5194/hessd-5-547-2008

Gabitov R.I, Watson E.B. \& Sadekov A., 2012 - Oxygen isotope fractionation between calcite and fluid as a function of growth rate and temperature: An in situ study. Chemical Geology, 306-307: 92-102.

https://doi.org/10.1016/j.chemgeo.2012.02.021

Haude W., 1955 - Zur Bestimmung der Verdunstung auf möglichst einfache Weise. Mitteilungen des Deutschen Wetterdienstes, 2: $24 \mathrm{p}$.

Hendy C.H., 1971 - The isotopic geochemistry of speleothems 1 . The calculation of the effects of the different modes of formation on the isotopic composition of speleothems and their applicability as palaeoclimatic indicators. Geochimica et Cosmochimica Acta, 35: 801824. https://doi.org/10.1016/0016-7037(71)90127-X

Hips K., 2003 - Gutenstein Formation in the Aggtelek facies of the Silica nappe. Földtani Közlöny, 133 (4): 445-468.

Holko L., Dóša M., Michalko J., Kostka Z. \& Šanda M., 2012 - Isotopes of oxygen-18 and deuterium in precipitation in Slovakia. Journal of Hydrology and Hydromechanics, 60 (4): 265-276. https://doi.org/10.2478/v10098-012-0023-2

Horita J. \& Clayton R.N., 2007 - Comment on the studies of oxygen isotope fractionation between calcium carbonates and water at low temperatures by Zhou and Zheng (2003, 2005). Geochimica Cosmochimica Acta, 71: 3131-3135. https://doi.org/10.1016/i.gca.2005.11.033

Kele S ., Breitenbach S.F.M., Capezzuoli E., Meckler A.N., Ziegler M., Millan I.M., Kluge T., Deák J., Hanselmann K., John C.M., Yan H., Liu Z. \& Bernasconi S.M., 2015 - Temperature dependence of oxygen- and clumped isotope fractionation in carbonates: A study of travertines and tufas in the $6-95^{\circ} \mathrm{C}$ temperature range. Geochimica et Cosmochimica Acta, 168: 172-192. https://doi.org/10.1016/j.gca.2015.06.032 
Kennett D.J., Breitenbach S.F.M., Aquino V.V., Asmerom Y., Awe J., Baldini J.U.L., Bartlein P., Culleton N.J., Ebert C., Jazwa C., Macri M.J., Marwan N., Polyak V., Prufer K.M, Ridley H.R., Sodemann H., Winterhalder B. \& Haug G.H., 2012 - Development and disintegration of Maya political systems in response to climate change. Science, 338: 788-791.

https://doi.org/10.1126/science.1226299

Kim S.-T. \& O'Neil J.R., 1997 - Equilibrium and nonequilibrium oxygen isotope effects in synthetic carbonates. Geochimica et Cosmochimica Acta, 61: 3461-3475.

https://doi.org/10.1016/S0016-7037(97)00169-5

Kluge T., Riechelmann D.F.C., Wieser M., Spötl C., Sültenfuß J., Schröder-Ritzrau A., Niggemann S. \& Aeschbach-Hertig W., 2010 - Dating cave drip water by tritium. Journal of Hydrology, 394: 396-406. https://doi.org/10.1016/j.jhydrol.2010.09.015

Kohn M.J. \& Welker J.M., 2005 - On the temperature correlation of $\delta^{18} \mathrm{O}$ in modern precipitation. Earth and Planetary Science Letters, 231: 87-96. https://doi.org/10.1016/j.epsl.2004.12.004

Lachniet M.S., 2009 - Climatic and environmental controls on speleothem oxygen isotope values. Quaternary Science Reviews, 28 (5-6): 412-432.

https://doi.org/10.1016/j.quascirev.2008.10.021

Mangini A., Spötl, C. \& Verdes P., 2005 - Reconstruction of temperature in the Central Alps during the past 2000 yr from a $\delta^{18} \mathrm{O}$ stalagmite record. Earth and Planetary Science Letters, 234: 741-751.

https://doi.org/10.1016/j.eps1.2005.05.010

Mattey D., Lowry D., Duffet J., Fisher R., Hodge E. \& Frisia S., 2008 - A 53 year seasonally resolved oxygen and carbon isotope record from a modern Gibraltar speleothem: Reconstructed drip water and relationship to local precipitation. Earth and Planetary Science Letters 269: 80-95.

https://doi.org/10.1016/j.epsl.2008.01.051

McGillen M.R. \& Fairchild I.J., 2005 - An experimental study of incongruent dissolution of $\mathrm{CaCO}_{3}$ under analogue glacial conditions. Journal of Glaciology, 51 (174): 383390. https://doi.org/10.3189/172756505781829223

Meckler A.N., Affolter S., Dublyansky Y.V., Krüger Y., Vogel N., Bernasconi S.M., Frenz M., Kipfer R., Leuenberger M., Spötl C., Carolin S., CobbK.M., Moerman J., Adkins J.F. \& Fleitmann D., 2015 Glacial-interglacial temperature change in the tropical West Pacific: A comparison of stalagmite-based paleothermometers. Quaternary Science Reviews, 127: 90-116. https://doi.org/10.1016/j.quascirev.2015.06.015

Meyer M.C., Spötl C. \& Mangini A., 2008 - The demise of the Last Interglacial recorded in isotopically dated speleothems from the Alps. Quaternary Science Reviews 27: 476-496.

https://doi.org/10.1016/j.quascirev.2007.11.005

Mickler P.J., Stern L.A. \& Banner J.L., 2006 - Large kinetic isotope effects in modern speleothems. Geological Society of America Bulletin 118 (1-2): 65-81. https://doi.org/10.1130/B25698.1

Mischel S.A., Scholz, D. \& Spötl C., $2015-\delta^{18} O$ values of cave drip water: a promising proxy for the reconstruction of the North Atlantic Oscillation? Climate Dynamics, 45: 3035-3050.

https://doi.org/10.1007/s00382-015-2521-5

Molnár M., Janovics R., Major I., Orsovszki J., Gönczi R., Veres M., Leonard A.G., Castle S.M., Lange T.E., Wacker L., Hajdas I. \& Jull A.J.T., 2013a - Status report of the new AMS C-14 sample preparation lab of the Hertelendi Laboratory of Environmental Studies, Debrecen, Hungary. Radiocarbon, 55: 665-676.

https://doi.org/10.1017/S0033822200057829
Molnár M., Rinyu L., Veres M., Seiler M., Wacker L. \& Synal H.-A., 2013b - EnvironMICADAS: a mini 14C-AMS with enhanced gas ion source interface in the Hertelendi Laboratory of Environmental Studies (HEKAL), Hungary. Radiocarbon, 55: 338-344.

https://doi.org/10.1017/S0033822200057453

Molnár M., Dezső Z., Futó I., Rinyu L. \& Svingor É., 2007 - Izotópanalitikai vizsgálatok a Baradla-barlang cseppköveiről csepegö vizeken. Karsztfejlődés, 12: 267-278.

Mühlinghaus C., Scholz D. \& Mangini A., 2007 - Modelling stalagmite growth and $\delta^{13} \mathrm{C}$ as a function of drip interval and temperature. Geochimica et Cosmochimica Acta, 71: 2780-2790.

https://doi.org/10.1016/j.gca.2007.03.018

Mühlinghaus C., Scholz D. \& Mangini A., 2009 Modelling fractionation of stable isotopes in stalagmites. Geochimica et Cosmochimica Acta, Acta 73: 7275-7289. https://doi.org/10.1016/i.gca.2009.09.010

Regattieri E., Zanchetta G., Drysdale R.N., Isola I., Hellstrom J.C. \& Roncioni A., 2014 - A continuous stable isotope record from the penultimate glacial maximum to the Last Interglacial (159-121 ka) from Tana Che Urla Cave (Apuan Alps, central Italy). Quaternary Research 82: $450-461$

https://doi.org/10.1016/j.yqres.2014.05.005

Riechelmann D.F.C., Schröder-Ritzrau A., Scholz D., Fohlmeister J., Spötl C., Richter D.K. \& Mangini A., 2011 - Monitoring Bunker Cave (NW Germany): A prerequisite to interpret geochemical proxy data of speleothems from this site. Journal of Hydrology, 409: 682-695.

https://doi.org/10.1016/j.jhydrol.2011.08.068

Riechelmann D.F.C., Deininger M., Scholz D., Riechelmann S., Schröder-Ritzrau A., Spötl C., Richter D.K., Mangini A. \& Immenhauser A. 2013 - Disequilibrium carbon and oxygen isotope fractionation in recent cave calcite: Comparison of cave precipitates and model data. Geochimica et Cosmochimica Acta, 103: 232-244. https://doi.org/10.1016/j.gca.2012.11.002

Riechelmann, S., Schröder-Ritzrau, A., Spötl, C., Riechelmann, D.F.C., Richter, D.K., Mangini, A., Frank, N., Breitenbach, S.F.M. \& Immenhauser, A., 2017 - Sensitivity of Bunker Cave to climatic forcings highlighted through multi-annual monitoring of rain-, soil-, and dripwaters. Chemical Geology, 449: 194-205. https://doi.org/10.1016/j.chemgeo.2016.12.015

Rozanski K., Araguás-Araguás L. \& Gonfiantini R., 1993 - Isotopic patterns in modern global precipitation, in Climate Change. In: Swart P.K., Lohmann K.C., McKenzie J. \& Savin S. (Eds.), Continental isotopic records. Geophysical Monograph Series 78, American Geophysical Union, Washington D.C., p 1-6.

Scholz D., Mühlinghaus C. \& Mangini A., 2009 Modelling $\delta^{13} \mathrm{C}$ and $\delta^{18} \mathrm{O}$ in the solution layer on stalagmite surfaces. Geochimica et Cosmochimica Acta, 73: 2592-2602.

https://doi.org/10.1016/j.gca.2009.02.015

Serefiddin F., Schwarcz H., Forda D.C. \& Baldwin S., 2004 - Late Pleistocene paleoclimate in the Black Hills of South Dakota from isotope records in speleothems. Palaeogeography, Palaeoclimatology, Palaeoecology, 203 (1-2): 1-17.

https://doi.org/10.1016/S0031-0182(03)00639-4

Sherwin C.M. \& Baldini J.U.L., 2011 - Cave air and hydrological controls on prior calcite precipitation and stalagmite growth rates: Implications for palaeoclimate reconstructions using speleothems. Geochimica et Cosmochimica Acta, 75: 3915-3929. https://doi.org/10.1016/j.gca.2011.04.020 
Siklósy Z., Demény A., Leél-Őssy Sz., Szenthe I., Lauritzen S.E. \& Shen C.C., 2011 - A cseppkövek kormeghatározása és azok paleoklimatológiai jelentősége. Földtani Közlöny 141: 73-87.

Siklósy Z., Demény A., Vennemann T.W., Pilet S., Kramers J., Leél-Össy Sz., Bondár M., Shen C.C. \& Hegner E., 2009a - Bronze Age volcanic event recorded in stalagmites by combined isotope and trace element studies. Rapid Communication in Mass Spectrometry 23: 801-808. https://doi.org/10.1002/rcm.3943

Siklósy Z., Demény A., Szenthe I., Leél-Össy Sz., Pilet S., Lin Y. \& Shen C.C., 2009b - Reconstruction of climate variation for the last millennium in the Bükk Mountains, northeast Hungary, from a stalagmite record. Időjárás, 113: $245-263$.

Smith A.C., Wynn P.M., Barker P.A., Leng M.J., Noble S.R. \& Stott A., 2016 - Cave monitoring and the potential for palaeoclimate. reconstruction from Cueva de Asiul, Cantabria (N. Spain). International Journal of Speleology. 45 (1): 1-9.

https://doi.org/10.5038/1827-806X.45.1.1928

Spötl C. \& Mattey D., 2012 - Scientific drilling of speleothems - a technical note. International Journal of Speleology. 41 (1): 29-34.

https://doi.org/10.5038/1827-806X.41.1.4

Spötl C. \& Vennemann T.W., 2003 - Continuous-flow isotope ratio mass spectrometric analysis of carbonate minerals. Rapid communications in mass spectrometry, 19 (9): 1004-1006. https://doi.org/10.1002/rcm.1010

Spötl C., Fairchild I. \& Tooth A.F., 1995 - Cave air control on dripwater geochemistry, Obir Caves (Austria): Implications for speleothem deposition in dynamically ventilated caves. Geochimica et Cosmochimica Acta, 69 (10): 2451-2468.

https://doi.org/10.1016/j.gca.2004.12.009

Szalai S., Auer I., Hiebl J., Milkovich J., Radim T., Stepanek P., Zahradnicek P., Bihari Z., Lakatos M., Szentimrey T., Limanowka D., Kilar P., Cheval S., Deak Gy., Mihic D., Antolovic I., Mihajlovic V., Nejedlik P., Stastny P., Mikulova K., Nabyvanets I., Skyryk O., Krakovskaya S., Vogt J., Antofie T. \& Spinoni J., 2013 - Climate of the Greater Carpathian Region. Final Technical Report. www.carpatclim-eu.org

Tan L., Cai Y., An Y., Cheng H., Shen C.C., Breitenbach S.F.M., Gao Y., Edwards R.,L., Zhang H. \& Du Y., 2015 - A Chinese cave links climate change, social impacts, and human adaptation over the last 500 years. Scientific Reports, 5: 12284.

https://doi.org/10.1038/srep12284

Tremaine D.M. \& Froelich P.N., 2013 - Speleothem trace element signatures: A hydrologic geochemical study of modern cave dripwaters and farmed calcite. Geochimica et Cosmochimica Acta, 121: 522-545.

https://doi.org/10.1016/j.gca.2013.07.026

Tremaine D.M., Froelich P.N. \& Wang Y., 2011 - Speleothem calcite farmed in situ: Modern calibration of $\delta^{18} \mathrm{O}$ and $\delta^{13} \mathrm{C}$ paleoclimate proxies in a continuously-monitored natural cave system. Geochimica et Cosmochimica Acta, 75: 4929-4950.

https://doi.org/10.1016/j.gca.2011.06.005

Van Rampelbergh M., Verheyden S., Allan M., Quinif Y., Keppens E. \& Claeys P., 2014 -Monitoring of a fast-growing speleothem site from the Han-sur-Lesse cave, Belgium, indicates equilibrium deposition of the seasonal $\delta 180$ and $\delta 13 \mathrm{C}$ signals in the calcite. Climate of the Past, 10: 1871-1885. https://doi.org/10.5194/cp-10-1871-2014

Vodila G., Palcsu L., Futó I. \& Szántó Zs., 2011 - A 9-year record of stable isotope ratios of precipitation in Eastern Hungary: Implications on isotope hydrology and regional palaeoclimatology. Journal of Hydrology, 400: 144-153.

https://doi.org/10.1016/j.jhydrol.2011.01.030

Wainer K., Genty D., Blamart D., Daëron M., BarMatthews M., Vonhof H., Dublyansky Y., PonsBranchu E., Thomas L., van Calsteren P., Quinif Y. \& Caillon N., 2011 - Speleothem record of the last 180 $k a$ in Villars cave (SW France): Investigation of a large $\delta^{18} \mathrm{O}$ shift between MIS6 and MIS5. Quaternary Science Reviews, 30: 130-146.

https://doi.org/10.1016/j.quascirev.2010.07.004

Watkins J.M., Hunt J.D., Ryerson F.J. \& DePaoloc D.J., 2014 - The influence of temperature, $p H$, and growth rate on the $\delta^{18} \mathrm{O}$ composition of inorganically precipitated calcite. Earth and Planetary Science Letters, 404: 332343. https://doi.org/10.1016/j.epsl.2014.07.036

Wong C.I., Banner J.L., \& Musgrove M., 2011 - Seasonal dripwater $\mathrm{Mg} / \mathrm{Ca}$ and $\mathrm{Sr} / \mathrm{Ca}$ variations driven by cave ventilation: Implications for and modeling of speleothem paleoclimate records. Geochimica et Cosmochimica Acta, 75: 3514-3529.

https://doi.org/10.1016/j.gca.2011.03.025 